\title{
SOME REMARKS ON THE ‘SHECHITA CASE’ OF THE ECJ
}

\section{György MARINKÁS ${ }^{1}$}

This study strives to answer why the European Court of Justice's (ECJ) 'Centraal Israëlitisch Consistorie van België'judgment, delivered on 17 December 2020, triggered heated reactions. Similarly, sharp criticisms were articulated regarding the recent decision of the Belgian Constitutional Court (Grondwettelijk Hof), where the Court upheld the national legislation on the ban of slaughter without prior stunning per the aforementioned ECJ judgment. This study examines the historic, theological, and scientific background of shechita and halal slaughter with reference to the aforementioned framework. Furthermore, the study strives to introduce the pros and cons of the issue to help the reader decide whether the ritual slaughter - the slaughter of animals without prior stunning but following certain rules aimed at sparing animals from useless suffering - is as humane as the modern non-religious method, where the slaughter is conducted with prior stunning. This study also examines the different theological interpretations on the acceptability of stunning animals before slaughter. In the second part, the study briefly introduces the freedom of religion-related case law of the European Court of Human Rights, and thoroughly analyses its Cha'are Shalom ve Tsedek decision. Moreover, it examines the ECJ's two ritual slaughter cases, namely the Liga van Moskeeën and Euvre d'assistance cases, which preceded the Centraal Israëlitisch Consistorie van Belgiëcase. As a brief excursus into the jurisprudence of the national constitutional courts, this study also introduces two cases brought by the constitutional courts of Germany and Poland. Finally, the third part thoroughly analyses the Advocate General's opinion and the judgment delivered in the Centraal Israëlitisch Consistorie van België case of the ECJ to highlight the reasons for the different interpretations of the very same EU law.

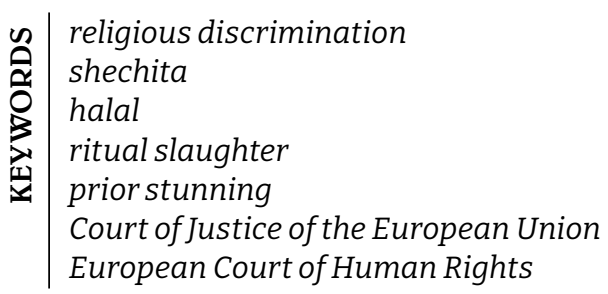

1| Researcher, Ferenc Mádl Institute of Comparative Law, gyorgy.marinkas@mfi.gov.hu.

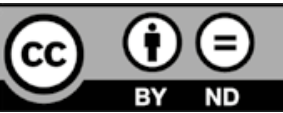




\section{Introduction}

The European Court of Justice (ECJ) delivered its judgment ${ }^{2}$ on 17 December 2020, and adjudged that '[the law of the European Union] must be interpreted as not precluding legislation of a Member State which requires, in the context of ritual slaughter, a reversible stunning procedure which cannot result in the animal's death.' This judgment sparked a vivid political debate. Similarly, sharp criticisms ${ }^{3}$ were articulated regarding the recent decision $^{4}$ of the Grondwettelijk Hof, the Belgian Constitutional Court, where the Court upheld the national legislation on the ban of slaughter without prior stunning per the aforementioned ECJ judgment.

This ECJ judgment is of interest to experts in European Union (EU) law, because, as highlighted by Advocate General Gerard Hogan in his opinion ${ }^{5}$, it was the first case where the ECJ analysed Article 26 (2/1) point ' $c$ ' of Regulation No. 1099/2009/EC of the Council ${ }^{6}$ (hereafter: Regulation) and decided on its validity. First, it should be noted that according to Article 4 (1) of the Regulation, the legislature of the European Union considers slaughter with prior stunning as a rule and only allows ritual slaughter as an exemption based on Article 4 (4). Contrarily, Article 26 (2/1) point 'c' of the Regulation allows the Member States,

'[to] adopt national rules aimed at ensuring more extensive protection of animals at the time of killing than those contained in this Regulation in relation to the following fields [...] the slaughtering and related operations of animals in accordance with Article 4 (4).'

These rules, aimed at promoting animal welfare, typically impose severe restrictions on the exemption granted by Article 4 (4) of the Regulation. Due to this contradiction between the two paragraphs, the question arise, where the 'scale-beam' finds its point of equilibrium when the considerations of animal welfare and the right to religious freedom are placed on this 'theoretical scale.'

However, there is nothing new under the sun. Debates focused on the conformity of shechita and 'European values' have been ongoing since the end of the $19^{\text {th }}$ century. Although some who advocated against shechita were truly driven by animal welfare

2 | C-336/19. sz. Centraal Israëlitisch Consistorie van België and Others case, Judgment of the Grand Chamber, 17 December 2020, para. 96

3 | 'Ruling brings Belgium into line with countries whose bans on Shechita date from the Nazi era,' says president of Conference of European Rabbis.' See: Jeremy Sharon, Belgian court upholds ban on religious slaughter. The Jerusalem Post (30 September 2021) [Online]. Available at: https://www. jpost.com/diaspora/belgian-court-upholds-ban-on-religious-slaughter-680733 (Accessed: 1 October 2021).

4 | Grondwettelijk hof, arrêt n 117/2021 du 30 september 2021; Grondwettelijk hof, arrêt n 118/2021 du 30 september 2021; See furthermore: Stephanie Romands, Brussels minister voor Dierenwelzijn legt verbod onverdoofd slachten op tafel. De Tijd (30 September 2021) [Online]. Available at: https:// www.tijd.be/politiek-economie/belgie-brussel/Brussels-minister-voor-Dierenwelzijn-legtverbod-onverdoofd-slachten-op-tafel/10335743 (Accessed:1 October 2021).

5 | C-336/19, Centraal Israëlitisch Consistorie van België and Others case, opinion of Advocate General Gerard Hogan, 10 September 2020, para.13.

6 | Council Regulation (EC) No 1099/2009 of 24 September 2009 on the protection of animals at the time of killing (OJ L 303, 18.11.2009, pp. 1-30). 
concerns, sadly enough, anti-Semitic overtones were audible from the very beginning. Owing to the anti-Semitism that peaked and resulted in an inconceivable tragedy during the second quarter of the $20^{\text {th }}$ century, shechita was banned in most European countries. Dark eras of history still cast their shadows on debates about shechita, and more recently on debates about halal slaughter. It is up to the legislature to find the proper balance between the right to religious freedom and animal welfare considerations, which is backed by ever-growing societal support. Consequently, the latter one too, can be considered as public interest. While the religious groups claim the primacy of shechita and halal slaughter as core elements of their religion, there is increasing pressure from the other side to consider animal protection and welfare concerns as far as possible. All of these are expected to be achieved in an era when anti-Semitism, and generally xenophobia, are on the rise. The latter induces the 'same old fears' in the Jewish community for obvious reasons.

To find the abovementioned equilibrium, the legislature needs to be acquainted with the religious freedom-related case-law of the European Court of Human Rights (ECtHR) and the ECJ alongside the two religious slaughter-related decisions delivered by the German and Polish constitutional courts respectively. Despite the ECtHR's longestablished case law in protecting human rights, it was not until the last quarter of a century that the Court had elaborated on the issue, and provided an extended and precise case law. This study presents a brief overview of the ECtHR's case law and analyses only the most relevant judgment in detail. Contrary to the ECtHR, the ECJ did not deliver a single judgment on the freedom of religion from 2009 - when the Charter of Fundamental Rights of the European Union ${ }^{7}$ (EU Charter) was vested with binding legal power - until 2017. However, the ECJ remedied this omission and delivered several decisions related to religious freedom; three of them concerned religious slaughter. Two of these three judgments delivered by the ECJ on religious slaughter ${ }^{8}$ are introduced in section two, while the third one is introduced in section three. This was decided because of the judgment's novelty, and the significant difference in the interpretation of EU law by the Advocate General and the Court. Therefore, the author believes that the said case deserves a more thorough examination and a separate section.

Lastly, the author introduces the research findings, including the scientific and religious arguments, introduced in the first section - pro and con. When doing so, the author wishes to indicate that he will dispense with expressing any personal views on the topic for two reasons: first, he does not possess thorough knowledge in either the field of theological or veterinary sciences. Second, neither Islamic scholars nor veterinary professionals can reach a consensus within their own circles, even if some tendencies may be observed in the case of scientific opinions. Thus, the summarizing part evaluates only the proper or improper nature of evaluating EU law by the Advocate General and court. 


\section{Historic, Theological and Scientific Background of Shechita and Halal Slaughter}

\section{| 1.1. An insight into the historic background}

It is important to understand the historical side of the issue to reveal the possible historic reasons that made some part of the believers of Judaism react in such a heated manner to the Flemish legal regulation and the ECJ judgment of December 2021, in which the Court stated the national regulation's conformity with EU law.

The aforementioned reasons shall be pursued in the emancipation progress of the Jews, which mostly took part in the $19^{\text {th }}$ century, and in the culmination of the antisemitism in the second quarter of the $20^{\text {th }}$ century. As Salo Wittmayer Baron ${ }^{9}$ noted, there is another interpretation of emancipation, which contradicts the well-established view that the emancipation of the Jews was the gift of the then-governments - mostly liberal and enlightened - to a group that 'existed outside society'. Contrary to the teachings of European history books, ${ }^{10}$ Baron argues ${ }^{11}$ that it was the modern egalitarian state that could not bear the differences in the legal status of society's different groups. Thus, the Jews had no option but to accept the deal, namely that they had to give up their autonomy related to their internal affairs in return for the rights and duties of a citizen. ${ }^{12}$ Consequently, the Jewish traditions and laws, which were regarded as obsolete and contradicting the principles and aims of enlightenment ${ }^{13}$, became discredited. Politicians and philosophers of the era firmly believed that Jews should assimilate into mainstream society and adopt their Christian values to the greatest extent possible. To achieve this, Jews were made to accept the stigmatization of their laws and customs, and their prevalence was restricted or banned. These laws and customs included: (i) Jewish matrimonial law, (ii) circumcision, (iii) Jewish burial customs, and (iv) the use of the mikvah, the place to take the ritual bath. Immanuel Kant named this process of assimilation as the 'euthanasia of Judaism' - well before the actual emancipation - and in his view, it was 'desirable'.14

Between the second half of the $19^{\text {th }}$ century and the first half of the $20^{\text {th }}$ century, the ban on shechita was in the centre of heated public and political debates in the German states (Länder), in Poland, and the Scandinavian countries. These debates formally addressed concerns regarding animal protection. In reality, they were tainted by anti-Semitism, however. In the then German Empire, the issue was called 'Rituelfragen', that is, the question of Jewish rituals. The Alliance for Animal Protection of the German Empire (Verband der Tierschutzvereine des Deutschen Reiches), established in 1881, launched a successful campaign against shechita. Subsequently, 'barbaric' and

9 | The late professor of the Columbia University - regarded as the 'greatest Jewish historian of the $20^{\text {th }}$ century' by many.

10 | This view is shared by Chapter 15 of the current Hungarian history book applicable according to the national curricula. See: Borhegyi, no date

11 | Baron, 1938, pp. 59-60.

12 | It is worth mentioning that acts on personal status of the Middle Eastern countries still distinguish between the citizens based on their religious affiliation. For a detailed analysis, please see: Marinkás, 2021b, p. 74.

13 | See: Lucci, 2008, p. 178.

14 | Kant, 1992, p. 217. 
'ruthless' practices were banned in several states of the German Empire. The federal ban on shechita was imposed in April 1933,,$^{15}$ shortly after Adolf Hitler emerged to power. The ban was incorporated into the law ${ }^{16}$ in November of the same year. ${ }^{17}$ In accordance with the mainstream tendencies, the Polish legislature (Sejm) enacted a law ${ }^{18}$ in 1936 that as a rule required the prior stunning of animals. However, Article 5 (1) of the law provided that the Minister for Agriculture may issue a regulation ${ }^{19}$ establishing particular rules for the ritual slaughter that serves the purposes of particular groups, whose religion requires special treatment. An amendment, which was adopted in the spring of 1939, completely banned religious slaughter. However, the outbreak of World War II prevented its ratification by the Senate. This 1936 law was formally repealed in 1997. ${ }^{20}$ The Scandinavian countries also imposed their own bans on slaughter without prior stunning: Finland in 1902 by decree, Norway and Sweden by statute in 1929 and 1937, respectively. Denmark brought a similar law; however, shechita was exempted from the general ban. Based on records of the parliamentary debates on the Norwegian and Swedish laws, parliamentary speeches ${ }^{21}$ of the time were commonly saturated by anti-Semitic arguments. ${ }^{22}$

15 | Delahunty, 2015, pp. 364-365.

16 | Das Deutsche Reichs Tierschutzgesetz vom 24. November 1933

17| The animal protection law of the Third Reich, adopted on 24 November 1933, was the first animal protection law in Germany. Unfortunately, the act is saturated with Nazi ideology and antiSemitism. See: Jütte, 2002, p. 183.

18 | Journal of Laws (Dz. U.) no. 29, item 237.

19 | Rozporządzenie Ministra Rolnictwa i Reform Rolnych z dnia 26 sierpnia 1936 r. wydanego w porozumieniu z Ministrem Wyznań Religijnych i Oświecenia Publicznego oraz Ministrem Spraw Wewnętrznych o sposobach i warunkach uboju rytualnego zwierząt gospodarskich, Journal of Laws (Dz. U.) No. 70, item 504.

20 | Skóra, 2019, pp. 288-290.

21 | Delahunty, 2015, pp. 366.

22 | There is an argument in the scientific literature - namely the article of Michael F. Metcalf - which suggests that anti-Semitic motivation of the above mentioned Scandinavian legislative procedures - the Norwegian and the Swedish respectively -, is proven by the fact that traditional hunting methods of the Sámi people were exempted from the prohibition of slaughtering animals without prior stunning. First of all, the author of the current article notes that Metcalf in his 1989 article referred to the Sámi people as Lapps, which - however was commonly used to name them in the past - is an offensive exonym used by the majority population of their respective countries. Secondly, while the author agrees with Metcalf that the Scandinavian ban on shechita in the past century was motivated by anti-Semitism, the author rejects Metcalf's argument that the exemption granted to the Sámi people is a proof of anti-Semitism. As the author of the current writing points out in his PhD dissertation - and his monographic writing based on his dissertation - these exemptions, which are still in force in Finland and Sweden and also constitute part of the two country's EU accession treaties -, are necessary for the mere existence of the otherwise vulnerable indigenous groups. See: Metcalf, 1989, pp. 47-48.; See also: Marinkás, 2018, pp. 45, 234, 293; Marinkás, 2016, pp. 45, 205 and 244; for an analysis of the protection of indigenous peoples' traditional way of life through the spectacles of the religious freedom, see: Krajnyák, 2020, p. 100. 
Summarising the above historic introduction, and having regarded the fact that antiSemitism is on the rise again ${ }^{23}$ the author is not surprised that a group of believers in the Jewish faith felt they were hit hard by the Flemish ban on shechita, the ECJ decision, and the recent judgment of the Grondwettelijk Hof. This is especially the case if one regards the fact that it restricts a religious custom, which was left intact during the emancipation and constitutes one of the core elements of their faith.

\subsection{Theological background of the shechita and halal slaughter}

It is worth examining the importance of shechita in Jewish religion and its scientific background. It should be noted that this custom dating back to thousands of years serves hygienic purposes, aiming at enhancing the preservability of meat, and is driven by the intention to reduce the suffering of animals during slaughter. Therefore, this study examines whether these strict religious instructions demand unconditional prevalence based on religious doctrines, considering that today's modern slaughter techniques can provide the prevalence of animal welfare considerations and religious prescriptions at the same time.

First, we should examine the meaning of shechita. What are the religious grounds of shechita, and what are the practical implications that verify religious prescriptions? How do shechita and halal slaughter compare to each other? ${ }^{24}$ Since the two methods are very similar and share two cardinal prescriptions, they shall be examined together. The first cardinal requirement is that the animal's neck should be cut with a sharp knife and the edge should not have chips. This enables the kosher butcher, the shochet, ${ }^{25}$ to slit the gullet, trachea, cervical artery, and vein of the animal with one determined move. The cervical vertebrae should remain intact during this process. While the shechita shall be performed only by the shochet, halal slaughter can be conducted by any grown person with true faith in Islam. Moreover, when such a person is unavailable, the slaughter may be conducted by a Christian or Jewish butcher, provided that they follow the prescriptions of Islam during slaughter. The second cardinal requirement is that the animal should die of bleeding, and the blood has to be drained out from the animal's corpse to the greatest extent possible.

Regarding the first, it shall be examined what the Jewish and Islamic scriptures say about the slaughter of animals. The Fifth Book of Moses (Elleh Haddebarim) only says that

23 | The scientific literature is divided on the possible causes of this growth, while some research indicate that the growth in the proportion of Muslim population - which is induced among others by immigration - clearly plays a role, other researches deny the existence of such nexus. However, it is a fact that during the research carried out by the European Union's Fundamental Rights Agency (FRA) in 2019, the members of the Jewish community reported the clear rise of anti-Semitism, and that they perceive the continuous growth of the Muslim community as a threat. It has to be noted regarding the latter that the victims of anti-Semitic attacks described their attackers as 'someone with a Muslim extremist view.' See: FRA, Young Jewish Europeans: perceptions and experiences of antisemitism (04 July 2019) [Online]. Available at: https://fra.europa.eu/en/publication/2019/youngjewish-europeans-perceptions-and-experiences-antisemitism\#TabPubKeyfindings1 (Accessed: 24 September 2021); See also: Stremmelaar and Lucassen, 2018, pp. 7-11; Siegel, 2018, pp. 432-433. 24 | Bartosiewicz, Csiky and Gyarmati, 2008, p. 133.

25 | Raj Tamás: A Sachjet. [Online]. Available at: http://www.zsido.hu/ujelet/archiv/u990311.html (Accessed: 24 September 2021). 
'you may slaughter any of your herd or flock he has given you, as I have commanded you.'26 The Torah is silent about the details. However the Book of Education (Sefer ha-Chinuch) - which explains the Torah's text - suggests that the shechita aims to reduce the time of the animal's agony and to minimize its suffering. This is achieved by cutting the animal's neck 'ear-to-ear'. ${ }^{27}$ Unlike its Jewish counterpart, the Islamic prescription on slaughter contains expressis verbis provision on the clemency towards animals during slaughter. Hadith 17 tells every Muslim that 'if you kill, kill well; and if you slaughter, slaughter well. Let each one of you sharpen his blade and let him spare suffering to the animal he slaughters.'28 This is supplemented by a Hadith of Prophet Muhammad:

'A good deed done to an animal is as meritorious as a good deed done to a human being, while an act of cruelty to an animal is as bad as an act of cruelty to a human being. ${ }^{29}$

However, it is not all about the mercy of animals. There is also the human side of ritual slaughter, namely that considering slaughtering as a sacred ritual reduces feelings of guilt when killing an animal. ${ }^{30}$

\subsection{The science beyond the theological prescriptions}

Those who argue for the humanity of shechita and halal slaughter claim that both methods fulfil the criteria on mercy, provided that the shechita and halal slaughter are conducted with a proper tool and in a proper way, then the animal shall lose consciousness within seconds. The 2001 guidelines ${ }^{31}$ of the Food and Agriculture Organization of the United Nations (UNFAO) support this opinion. As the document states, both shechita and halal slaughter are acceptable from an animal welfare perspective, provided that certain 'appropriate' rules are obeyed. The results of scientific research also support these findings. ${ }^{32}$ Stuart D. Rosen argues that shechita is a 'painless and effective method'. ${ }^{33}$ The study $^{34}$ by Lerner and Rabello, and the 2003 study $^{35}$ of the Italian National Committee of Bioethics (Comitato Nazionale per la Bioetica, CNB) also argue in favour of shechita, claiming that it is a humane way of slaughter. The CNB holds that there is no way to determine which method - namely, slaughter with prior stunning or ritual slaughter without prior stunning - causes less suffering to animals. Grandin and Regenstein ${ }^{36}$ - in their study

26 | Deuteronomy 12:20-22 (Christian Standard Bible version from the website Bible Gateway) [Online]. Available at: https://www.biblegateway.com/passage/?search=Deuteronomy\%20 12:20-228version=CSB (Accessed: 24 September 2021).

27 | Rabbi Chanoch Kesselman from the Union of Orthodox Hebrew Congregations (London): 'The rules of Shechita for performing a proper cut during kosher slaughter.' [Online]. Available at: https:// www.grandin.com/ritual/rules.shechita.proper.cut.html (Accessed: 24 September 2021).

$28 \mid$ The Forty Hadith of Imam Nawawi, Hadith 17 [Online]. Available at: https://40hadithnawawi. com/hadith/17-prescription-of-ihsan-perfection/(Accessed: 24 September 2021).

29| Rahman and Phillips, 2017, p. 10.

30 | Salamano and Cenci-Goga, 2015, p. 9.

$31 \mid$ Heinz and Srisuvan, 2001, p. 91.

32 I One has to note however, that other studies have proven the opposite as well.

33 | Rosen, 2004, pp. 764-765.

34 | Lerner and Rabello, pp. 60-62.

35 | CNB, Ritual slaughtering and animal suffering. Approved in the Plenary session of the $19^{\text {th }}$ of September 2003. [Online]. Available at: http://bioetica.governo.it/media/3340/p57_2003_ritualslaughtering_en.pdf(Accessed: 24 September 2021).

36 | Grandin and Regenstein, 1994, pp. 120-123. 
written in 1994 - compared shechita and modern large-scale slaughter methods based on three aspects: (i) the stress caused by the tools used to restrict the animals before slaughter; (ii) the pain felt by the animals during slaughter, which can be deducted from the moves and the sounds made by the animal during its agony, and (iii) the average duration of time between the administration of the cut and the loss of consciousness. Grandin and Regenstein concluded, regarding their first criteria, that the 'bottleneck' of large-scale shechita slaughter is the method of restricting the animal, namely, the average duration of time between the restriction of the animal and the cut is administered. Therefore, large-scale shechita slaughter and large-scale non-religious slaughter share the same weaknesses.

The animal is restricted in its movement and strives to escape, driven by its natural instincts. Due to these fruitless efforts, the animal is exposed to severe stress. In the case of traditional or small-scale slaughter, this time is shorter. However, when the slaughter is performed on a large scale, there is more time-lapse, which does not conform to animal protection and welfare considerations. Here, it is worth mentioning that in the case of slaughter with prior stunning, the animal is not exposed to this stress, provided that the stunning was successful. Regarding the second and third criteria, Grandin and Regenstein concluded that the animals' experience of pain was minimal, and the loss of consciousness occurred in seconds. The latter shows great variety, however. Grandin and Regenstein admit that, in cases of certain species, the period may be significantly longer. Particularly, this could take 20 seconds for sheep, 25 seconds for pigs, and up to 2 minutes for cattle, according to the 2004 scientific report by the European Food Safety Authority (EFSA). ${ }^{37}$ Thus, considering their findings and animal welfare considerations, they make two recommendations, namely: (i) slaughter houses that perform large-scale shechita slaughter should revise and evaluate their methods to eliminate any unnecessary factors that induce stress among animals; (ii) the cut should be administered only by properly trained persons, and tools should be maintained in a proper condition according to the religious prescriptions. ${ }^{38}$ Obeying these religious prescriptions together with the secular institutional rules is the key to humane slaughter in Kaminski's view. ${ }^{39}$ He analyses the US regulation - namely, the Humane Methods of Slaughter Act (HMSA) ${ }^{40}$ - and argues that the 'obsessive focus on stunning as the sine qua non of animal welfare' blinds those advocating for animal rights. Thus, they neglect other tools suitable to ensure that slaughter is administered humanely. Kaminski identifies another problem, which is a phenomenon that he calls as the 'ritual bubble'. In his view, the ritual bubble is created by $\S 1906$ of the act that exempts religious slaughter from the rules and the supervision of the authority. Disobedience of rules has also been identified as an issue in other sources. The Animal Aid in a 2009 study - called the 'The humane slaughter myth'41 - supports these findings by revealing systemic problems at slaughterhouses in the United Kingdom. It also supports the findings of Grandin and Regenstein, namely that the animals are exposed to severe

37 | EFSA, 2004, pp. 27-29.

38 | Grandin and Regenstein, 1994, pp. 120-123.

39 | Kaminski, 2019, pp. 51-53.

40 | Humane Methods of Livestock Slaughter Act (P.L. 85-765; 7U.S.C.1901 et seq.) Approved: August 27, 1958.

41 | Animal Aid: The humane slaughter myth. An Animal Aid Investigation into UK Slaughterhouses (2009) Researched and written by Kate Fowler. p. 32. [Online]. Available at: https://www.animalaid. org.uk/wp-content/uploads/2016/10/slaughterreport.pdf (Accessed: 24 September 2021). 
stress, even if they are slaughtered with prior stunning. Additionally, animals usually witness how their fellows are stunned and then hung by their legs. Furthermore, Animal Aid's 2009 study reveals that the unsuccessful stunning - consequently, the hanging and slaughtering of conscious animals - is a more widespread phenomenon than the public would imagine. ${ }^{42}$ The proportion of unsuccessful stuns can range from $2 \%$ to $19 \%$ depending on the species of the animal, the capacity of the slaughterhouse, ${ }^{43}$ and the training of professionals who administer the stunning. ${ }^{44}$ Contrarily, those arguing in favour of shechita and halal slaughter claim that the animals should not be slaughtered in front of each other, and the animal should not witness the sharpening of the knife as per religious prescription. These prescriptions are aimed at reducing animal stress. ${ }^{45}$ They also argue that these requirements are difficult to fulfil in modern large-scale slaughterhouses.

Finally, to understand the so-called 'starting at home principle' advocated by Iddo Porat in his article, ${ }^{46}$ it is worth citing Will Kymlicka and Sue Donaldson:

'Dominant groups typically ignore the ways in which they are complicit in the abuse of billions of captive and enslaved domesticated animals, while complaining about the hunting practices of rural communities and indigenous peoples, or the ritual use of animals by religious minorities, even though these latter practices represent only a tiny fraction of abused animals

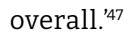

Porat argues that most Western societies accept many inhumane practices, such as branding and castrating animals without any anesthesia, and early separation of young calves from their mothers, which causes trauma and anxiety to both the mother and the calves. Furthermore, he provides statistical data and examples to prove that those inhumane practices accepted by the majority affect more animals than those slaughtered ritually by some minorities. Based on certain surveys, $18 \%-27 \%$ of animals are slaughtered outside licensed slaughterhouses, within the territory of the EU. These animals are slaughtered using inhumane methods without obeying the EU rules. Furthermore, Porat argues that several hunting techniques, especially hunting by traps cause prolonged suffering in animals. Moreover, the amount of pain experienced and its duration were significantly greater than in the case of shechita and halal. Even in the case of a gunshot, no one can take it for granted that the animal dies shortly after the hit. ${ }^{48}$

After examining the pros of the argument, one should examine its cons. Advocates of ritual slaughter argue that shechita and halal slaughter require the butchers to obey rules aimed at reducing the suffering of the animals during slaughter, which is difficult

42 I Ibid. pp. 7-14.; See furthermore: the expert opinion of the Academic Services of the German Parliament, expert opinion, Wissenschaftliche Dienste des Bundestages, "Videoaufzeichnungen in Schlachth6fen" WD 5 -

3000 - 042/18) (27 March 2018).

43 | Greater capacity comes with a greater proportion of unsuccessful stunning.

44 | Vecerek et al., 2020, p. 6; von Wenzlawowicz et al., 2012, pp. 59-60.

45 | Bartosiewicz, 2014, pp. 80-81.

46 | Porat, 2020, p. 3.

47 | Kymlicka and Donaldson, 2014, p. 122; For a detailed analysis of the protection of indigenous cultural heritage - including traditional hunting techniques -, please see: Marinkás, 2017, pp. 35-38.

48 | These arguments also emerged in the C-336/19 Centraal Israëlitisch Consistorie van België case, where the ECJ thoroughly elaborated on the matter and refuted these arguments. 
to fulfill in modern large-scale slaughterhouses. This is a convincing argument, but it fails when the large-scale slaughter is conducted in a temporary slaughterhouse to meet the extra demand for halal meat before a religious festival ${ }^{49}$. In such instances, it is simply impossible to obey the aforementioned prescriptions - for example, that animals shall not be slaughtered before each other -; thus, the preparatory acts of slaughter became ruthless as those in the case of large-scale non-religious slaughter. ${ }^{50}$ Anne Peters notes ${ }^{51}$ that those who refer to idealized religious practices to criticize non-religious slaughter practices as they happen in the real world are comparing apples with pears as religious practices are rarely followed to the letter.

Furthermore, it is not contested that the rules of shechita and halal slaughter - with their prescriptions aimed at the forbearance of animals - were ahead of their times. ${ }^{52}$ However, it is hard to negate the scientific facts proving that slaughter with prior stunning is the most humane way, even if the risk of potential suffering for the animal cannot be excluded with $100 \%$ accuracy. The current EU legislation on the matter - namely Council Regulation 1099/2009/EC - in its preamble cites such scientific documents including the $2004^{53}$ and $2006^{54}$ opinions of the EFSA - prove that slaughter with prior stunning is more humane than slaughter without prior stunning. The scientific works ${ }^{55}$ cited in the ECJ judgments and the consensus among veterinarians also verify this argument. The opinions of the EFSA emphasize that from an animal welfare perspective, only slaughter with prior stunning is acceptable. ${ }^{56}$ The Federation of Veterinarians of Europe in its 2002 position paper ${ }^{57}$ also shares this view. According to the position paper, a state of unconsciousness may occur only minutes after the cut is administered. This fact is admitted even by Grandin and Regenstein, the advocates of shechita slaughter. Furthermore, as Holleben and her fellow co-authors argue in their study, ${ }^{58}$ the animal may return to a state of consciousness before death occurs. These periods expose animals to stress and unnecessary suffering. Furthermore, if slaughter is carried out without prior stunning and proper restriction of the animal, including stretching of the neck in a way that enables the bleeding out in the shortest possible way, makes the whole process more circumstantial, which further increases the stress level of the animal. ${ }^{59}$ Based on this study, the new scientific research proves that Grandin and Regenstein were wrong and animals do feel pain when their necks are cut without prior stunning, with special regard

49 | See the ECJ's judgment delivered in the C-426/16, Liga van Moskeeën case, where the court had to decide on the conformity of a domestic law which regulates the creation of temporary slaughterhouses aimed at satisfying the temporary increase in the demand for halal meat before Eid al-Adha, the Muslim Feast of the Sacrifice. The said judgment is introduced in the second section of the article.

50 | Bartosiewicz, Csiky and Gyarmati, 2008, p. 145.

51 | Peters, 2019, pp. 296-298.

52 | The scriptures of Christianity do not contain a ban on eating blood since Christianity does not attribute soul to animals.

53 | EFSA, 2004, pp. 27-29.

54 | EFSA, 2006, pp. 17-18.

55 | von Holleben et. al., 2010, pp. 55-60.

56 | See: EFSA, 2020, pp. 59-60.; EFSA, 2014a, pp. 6-8; EFSA, 2013, p. 17.

57 | FVE, Slaughter of Animals Without Prior Stunning. FVE Position Paper (FVE/02/104 - Final) [Online]. Available at: https://fve.org/cms/wp-content/uploads/fve_02_104_slaughter_prior_ stunning.pdf (Accessed: 24 September 2021)

58 | von Holleben et. al., 2010, pp. 55-56.

59 | ibid., pp. 55-56. 
to the fact that the neck is rich in terminal nerves. This statement is solid even if the cut is administered by a well-trained person who uses a properly sharpened knife. ${ }^{60}$ Thus, as aforementioned, the animal is exposed to needless suffering if the loss of consciousness accidentally occurs only later.

Importantly, the scientific articles, studies, and reports that advocate in favour of shechita and halal slaughter - claiming that it is as humane as the slaughter with prior stunning - typically date back 15-20 years or earlier. ${ }^{61}$ For example, the abovementioned article of Grandin and Regenstein dates back to 1994, while all those writings argue in favour of slaughter with prior stunning are newer. Although this argument does not necessarily convince everyone, it reveals the current dominant tendency in scientific arguments. This tendency can be summarized as follows: while every technique of slaughter may possibly endanger the welfare of the animal - for example, in case the prior stunning is unsuccessful, the animal is exposed to unnecessary pain -, these risks are lowest when the slaughter is conducted with prior stunning.

The other commonly shared cardinal requirement of shechita and halal slaughter, namely the requirement for bleeding out, may be found in other religions and folk customs. Among others, it plays an important role in the Hungarian practice of pig slaughter, even though Christian religious prescriptions do not impose a ban on consuming blood. This ban in Jewish and Islamic religions is based on the belief that the blood contains the soul of the animal: these two exit the body of the animal together. This is how the soul returns to its creator. ${ }^{62}$ If one peels the religious/ideological shell of the prescription of bleeding out and examines these prescriptions from a sanitary viewpoint, it is clear that these requirements once served practical considerations: the residual blood in the corpse of the animal makes the meat less conservable. ${ }^{63}$ In other words, if one - living as a nomad in a desert environment, ${ }^{64}$ lacking any advanced preserving methods - aims to preserve the quality and edibility of the meat, it is essential to drain out the blood to the greatest extent possible. ${ }^{65}$ The latter is facilitated by the animal's own heart and blood circulation system, both of which function for a while after the cut is administered. However, the total drain-out is impossible from a scientific standpoint as a certain amount of blood always remains in the animal's corpse. ${ }^{66}$ The practice of koshering - rinsing the meat with water and soaking it entirely submerged in water than dry salting - aims at completely draining out the remaining blood from the animal's corpse.

Subsequently, it is worth examining whether the second cardinal element - namely that the animal has to die from bleeding - allows the stunning of the animal before slaughter. First, certain stunning techniques cause irreversible harm to the animal, that is, the animal's death is not caused by the bleeding out alone. Second, prior stunning may

60 | ibid., pp. 53-55.

61 | September 2021.

62 | 'But don't eat the blood, since the blood is the life, and you must not eat the life with the meat. Do not eat blood; pour it on the ground like water.' Deuteronomy 12, 23-24 (Christian Standard Bible version from the website Bible Gateway) [Online]. Available at: https://www.biblegateway.com/pass age/?search=Deuteronomy+12\%3A23-248version=CSB (Accessed: 24 September 2021].

63 | The scientific explanation is the following: the contagious blood from the dead animal's intestines flows back to the muscular tissues and spoils them.

64 I The fact that the custom of shechita dates back to the time of the 'Wandering in the Desert' supports the argument that bleeding out once served practical considerations.

65 | Kaminski, 2019, p. 34.

66 | Berényi, 2014, p. 63. 
have a detrimental effect on the effectiveness of the bleeding out; namely, less blood may be drained out. The significant difference between the regulations on shechita and halal must be noted here. While in the case of shechita, any stunning technique is forbidden. Muslim scholars are divided on this issue. ${ }^{67}$ The lack of consensus is attributable to two factors: (i) the less centralized nature of Islamic denominations, 68 and (ii) the lack of an expressis verbis ban on prior stunning in Islamic scriptures. Therefore, while some Muslim scholars maintain that prior stunning is not allowed, as there is a doubt that the animal's death is not caused by the bleeding out alone. Others argue that Hadith 17 requires that followers of the Islamic faith strive to reduce the suffering of the animal, provided that the most important rule, namely that the animal dies of bleeding out, and the blood drains out from its corpse to the greatest extent possible. ${ }^{69}$ This view is supported by the 1986 recommendation of the Muslim World League (Rabitat al-Alam-al-Islam) adopted jointly with the World Health Organization (WHO).$^{70}$ There are two things worth mentioning regarding the requirement of bleeding out. First, prior stunning does not affect the effectiveness of bleeding out, that is, it does not decrease the quantity of the blood drained out. Moreover, some research ${ }^{71}$ suggests that the electronarcosis ${ }^{72}$ - which is required by the Flemish law in the ECJ's C-336/19 case - increases the effectiveness of bleeding to a small extent. Second, the concept of completely bleeding out the animal is a mere fiction from a scientific standpoint as some blood always remains in the dead animal. That the residual blood needs to be removed from the animal's body by koshering to achieve the kosher quality is not coincidental.

\section{Freedom of Religion in the case law of the ECtHR, the pre-2020 case law of the ECJ, and a short excursus to the jurisprudence of two selected national constitutional courts}

\section{2.1. Grounding thoughts on the case law of the ECTHR and the ECJ on the freedom of religion}

Balázs Schanda and Annamária Csiziné Schlosser argue ${ }^{73}$ that the jurisprudence of the European Human Rights Mechanism on Article 9 of the European Convention on Human Rights (hereafter: European Convention) is very modest compared to other

67 | Farouk et al., 2014, pp. 518-519; Cuccurese et al., 2013, pp. 443-445.

68 | See: Benyusz, Pék and Marinkás, 2020, p. 161.

69 | The Halal Food Authority (HFA) also supports slaughter with prior stunning, provided that animal dies of the bleeding out. See: http://www.halalrc.org/(Accessed: 24 September 2021)

70 | WHO, Joint meeting of the League of Muslim World (LMW) and the World Health Organization (WHO) on Islamic rules governing foods of animal origin (held on 5-7 December 1985), WHO Doc WHO-EM/FOS/1-E (January 1986) at p. 8. [Online]. Available at: https:/apps.who.int/iris/ handle/10665/116451 (Accessed: 2021 September 24).

71 | Anil et. al., 2010, p. 2. Religious rules and requirements - Halal slaughter. Dialrel Reports (2010) [Online]. Available at: https://www.dialrel.net/dialrel/images/halal-rules.pdf (Accessed: 24 September 2021).

72 | For more information on the method see: Humane Slaughter Association, Electrical Stunning of Red Meat Animals Electronarcosis [Online]. Available at: https://www.hsa.org.uk/electricalstunning/electronarcosis (Accessed: 24 September 2021); See also: Végh, 2016, p. 68.

73 | Schanda and Csiziné Schlosser, 2009, pp. 67-69. 
articles of the said document. The European Commission on Human Rights (ECHR) which has been wound up ${ }^{74}$ since then - declared submissions related to the freedom of religion as applicable only in small numbers. Moreover, the ECtHR delivered its first judgment to state the violation of Article 9 only in the nineties of the last century. Some argue that this is because there are no severe problems with the prevalence of religious freedom in Europe. As Schanda and Csiziné Schlosser argue, other explanations exist. The ECtHR has 'remedied the omission,' and has delivered several judgments related to Article 9 in the meantime. Similar to the ECtHR, the ECJ also remained silent on the issue of religious freedom for a long time. This silence lasted from 2009, when the EU Charter was vested with binding legal power, till 2017, when the ECJ delivered its first religious freedom related decision. ${ }^{75}$ However, the ECJ remedied this 'omission' and delivered several decisions related to religious freedom. John Witte Jr. and Andrea Pin even call the ECJ the 'new boss of religious freedom.' Although this may seem to be an exaggerated expression first, they argue that the ECJ already showed a strong preference for 'state neutrality,' and provided a more nuanced analysis of religious freedom and enhanced protection for the said freedom. They argue that the ECJ performs better in this field than the ECtHR, which grants an ample 'margin of appreciation' for state parties, when it comes to 'laïcité' and secularization. Two phenomena, which Witte and Pin claims to be an 'aggressive [and harmful] ${ }^{76}$ policy trend' in some EU Member States. ${ }^{77}$

What can explain this enhanced activity in the case of both courts? The author hereby reminds the reader that in the second part of the current series of articles, he already stated that religiousness is on the rise in the $21^{\text {st }}$ century, which is an increasingly important determinant. ${ }^{78}$ However, the phenomenon, named 'desecularization,' by Peter Berger ${ }^{79}$ started earlier, at the end of the last century..$^{80}$ Those who explore religious beliefs ${ }^{81}$ are most likely to pick one of the fundamentalist branches. ${ }^{82}$ It is obvious that fundamentalist branches of religions are hard to be concealed with the expectations of

74 | Protocol No. 11 to the European Convention on Human Rights

75 | Witte Jr. and Pin, 2021, pp. 660-661.

76 | Interpreting addition by the author.

77 | Pin and Witte Jr., 2020, pp. 223-224.

78 | Marinkás, 2021b, p. 53.

79 | Berger, 1999, p. 8; See furthermore: Rosta, 2019, pp. 792-793.

80 | Berger's ideas are supported by the fact that the number of believers in Islamic religion is on a dynamic rise and this growth seems set to continue in the years to come according to forecasts. Although there is a rise in Christian religiousness, the rise in Islamic religiousness is more apparent. This phenomenon is more obvious in case of the Western European youngsters with a migratory background, who in most instances are more religious than their parents. See: EPRS (European Parliamentary Research Service): 'Religion and the EU's external policies - Increasing engagement', In-depth Analysis, February, 2020; Lipka and Hackett, 2017; Harriet Sherwood: Religion: why faith is becoming more and more popular. The Guardian (27 August 2018) [Online]. Available at: https:// www.theguardian.com/news/2018/aug/27/religion-why-is-faith-growing-and-what-happensnext (Accessed: 24 September 2021).

81 | Reiss, 2000, p. 47.

82 I The picture is more complex, however. The majority of the MENA region's population is clearly refused the ideologies of the ISIS/DAESH and those political actors who cooperated with the extremists. See: Arab Barometer (April 6, 2020) Is the MENA Region Becoming Less Religious? An Interview with Michael Robbins [Online]. Available at: https://www.arabbarometer.org/2020/04/ is-the-mena-region-becoming-less-religious-an-interview-with-michael-robbins/ (Accessed: 24 September 2021). 
the mainstream society and the idea of secularization. This was proven by the Cha'are Shalom ve Tsedek vs. France case $e^{83}$ of the ECtHR. The rise in religiousness is illustrated by the fact that the nexus between state and church, and also the nexus between politics and religion is once again at the centre of societal and political debates in certain European states. ${ }^{84}$ The ECtHR - maybe because of the 'desecularization trend'-delivered a relatively rich case law on religious freedom in the last 20-25 years. Shanda and Csiziné Schlosser argue that regarding the precedent nature of these judgments, certain conclusions can be drawn based on this case law. The current study introduces only those arguments that are relevant in this article: (i) the religious communities should have the right to obtain legal personality; ${ }^{85}$ (ii) a democratic state does not have the right to intervene in the domestic affairs of religious communities; 86 and (iii) expression of religious faith may be restricted, but these restrictions cannot be disproportionate. ${ }^{87}$

\subsection{Freedom of Religion in the case-law of the ECtHR and the Cha'are Shalom ve Tsedek case}

The Cha'are Shalom ve Tsedek is worth highlighting and analysing for several reasons, amongst others, for its similarities with the C-336/19 Centraal Israëlitisch Consistorie van België case of the ECJ. The case that is the focus of this study.

The facts of the case before the national court can be summarized as follows: based on a French decree of $1980,{ }^{88}$ ritual slaughter may be conducted only in licensed slaughterhouses that obey the rules. Religious communities may obtain a license from the state department responsible for agriculture based on the recommendation of the state department responsible for justice affairs. ${ }^{89}$ However, shechita was granted an exemption and the license was issued by the Association Consistoriale Israelite de Paris (ACIP), an umbrella organization of Jewish religious communities. In the case where there is no registered Jewish religious community in a given county, the license is issued by the prefect of the county. The association Cha'are Shalom ve Tsedek was aimed at cultural and educational purposes. In addition to its main activities, it endeavored to procure and deliver the 'glatt' (pure/smooth) meat to its members. The glatt meat is made per the prescriptions of the 'Shulchán Aruch' known as 'Set Table' or the 'Code of Jewish Law' written by Rabbi Joseph Karo during the $16^{\text {th }}$ century. It is one of the most orthodox branches of Judaism. The Cha'are Shalom ve Tsedek claimed that it can procure such meat only in Belgium, as the meat produced by the ACIP does not meet the requirement of glatt quality.

83 I ECtHR, Cha'are Shalom ve Tsedek v. France case, Judgment (27 June 2000). For the analysis of the case see: Békefi Judit: Vallásszabadság jogi szemszögből. Szombat (2016.07.09.) [Online]. Available at : https://www.szombat.org/politika/vallasszabadsag-jogi-szemszogbol (Accessed: 24 September 2021).

84 | Lásd: Benyusz, Pék and Marinkás, 2020, p. 173.

85 | ECtHR, Canea Catholic Church v. Greece, Judgment, 16 December 1997.

86 | ECtHR, Serif v. Greece, Judgment 14. December 1999; ECtHR, Hasan and Chaush v. Bulgaria, Judgment, 26 October 2000; ECtHR, The Metropolitan Church of Bessarabia and others v. Moldavia, Judgment, 13 December 2001; ECtHR, Agga v. Greece, Judgment 17 October 2002.

87 | ECtHR, Kokkinakis v. Greece, Judgment, 25 May 1993; ECtHR, Valsamis v. Greece, Judgement 18 December 1996; ECtHR, Kalaç v. Turkey, Judgment 1 July 1997; ECtHR, Larissis and others v. Greece, Judgment, 24 February 1988; ECtHR, Buscarini and others v. San Marino, Judgment, 18 February 1999

88 | Décret n ${ }^{\circ} 80-791$ du 1 octobre 1980 pris pour l'application de l'article 276 du code rural. 89 | ECtHR, Cha'are Shalom case, para. 48. 
Therefore, the Cha'are Shalom ve Tsedek submitted a claim for a license to produce glatt meat domestically. The ACIP rejected this application. ${ }^{90}$

Having regarded the traditionally secular attitude of the state (laïcité), which includes the separation of church and state, the French judicial system was unable to resolve the issue, where religious arguments conflicted with secular ones. After these unsuccessful attempts before domestic courts, the applicant submitted an application to the ECHR, which referred to the case before the ECtHR on 6 March 1999.91

Although the Grand Chamber held ${ }^{92}$ that there was 'no violation of Article 9 of the Convention taken alone [or] taken in conjunction with Article 14', the decision was far from unanimous. The judges decided on the first and second questions with a 12:5 and 10:7 ratio, respectively. Seven judges - who disagreed with the other ten regarding the second question in their joint dissenting opinion ${ }^{93}$ - argued that the majority opinion is not the only proper interpretation of the case. The ECtHR case law was elaborated on in the aforementioned article of Schanda and Csiziné Schlosser, which supports the opinion of the dissenting judges, instead of the majority opinion.

Accordingly, the Cha'are Shalom ve Tsedek and the French State dissented on three issues. First, the French state argued that the Cha'are Shalom ve Tsedek, which was registered as a cultural association, was not allowed to conduct any religious activities. ${ }^{94}$ The majority of judges approved this argument. ${ }^{95}$ However, the dissenting judges favoured the applicant and argued that the Cha'are Shalom ve Tsedek should be regarded as a religious association according to the 1905 Act on the separation of church and state. ${ }^{96}$ Their argument is supported by the fact that the aforementioned Decree of 1980 did not define 'religious organizations' and the criteria for being recognized as such an organization. ${ }^{97}$ Second, in conjunction with the preceding, it could be argued that the state's decision to grant exclusive rights to ACIP on decisions regarding the license constitutes the violation of Article 14 of the European Convention. While most judges accepted the French state's reasoning, namely, that the special status of the ACIP as an umbrella organization of the Jewish religious associations is necessary and proportional, the dissenting judges argued that respecting pluralism is the task of the state and not its elimination. As the dissenting judges argued that the notion of discrimination ordinarily includes cases where states treat persons or groups in analogous situations differently, without providing an objective and reasonable justification..$^{98}$ Although they acknowledge that

'[...] the fact that the State wishes to avoid dealing with an excessive number of negotiating partners so as not to dissipate its efforts and in order to reach concrete results more easily,

90 | ECtHR, Cha'are Shalom case, paras. 22-44.

91 | ECtHR, Cha'are Shalom case, paras. 1-2.

92 | ECtHR, Cha'are Shalom case, para. 88.

93 ECtHR, Cha'are Shalom case, Joint Dissenting Opinion of judges Sir Nicolas, Bratza, Fischbach,

Thomassen, Tsatsa-Nikolovska, Panțîru, Levits and Traja, para. 2.

94 | ECtHR, Cha'are Shalom case, paras. 69-70.

95 | ECtHR, Cha'are Shalom case, paras. 62, 67-69.

96 | La loi concernant la séparation des Églises et de l'État (1905).

97 | ECtHR, Cha'are Shalom case, Joint Dissenting Opinion, para. 2.

98 | ECtHR, Cha'are Shalom case, Joint Dissenting Opinion, para. 2. 
whether in its relations with trade unions, political parties or religious denominations, is not illegitimate in itself, or disproportionate. ${ }^{99}$

However, this may not result in differentiated treatment, without providing an objective and reasonable justification. According to them, in the case at hand, neither the alleged insufficient representativeness of the Cha'are Shalom ve Tsedek, nor the French state's other allegation - namely, the necessity to protect public order and public health - stands fast. The latter argument is especially weak, having regarded the fact that the French state is particularly gracious when it comes to licensing halal slaughterhouses, ${ }^{100}$ even though Muslim religious associations are much smaller in their membership and lack strict hierarchy. ${ }^{101}$ Thus, they do not possess such representativeness compared to the Jewish religious groups. Third, The Cha'are Shalom ve Tsedek argued the fact that it can procure glatt meat - the sole acceptable quality for its customers - only from foreign sources, constitutes the violation of Article 9 of the European Convention. The majority concluded that 'the right to freedom of religion guaranteed by Article 9 of the Convention cannot extend to the right to take part in person in the performance of ritual slaughter [...].'.102 The majority opinion further emphasizes that the applicant, contrary to its allegations, is able to procure meat from both domestic and foreign sources. Thus, there were no violations of Article $9 .{ }^{103}$ Contrarily, the dissenting judges argued that '[...] the fact that the applicant association is able to import 'glatt' meat from Belgium does not justify in this case the conclusion that there was no interference with the right to the freedom to practice one's religion through performance of the rite of ritual slaughter [...]' Thus, the state's regulation that excludes participation in such ceremonies infringes on the right of religious freedom. This is supported by the fact that the Decree of 1980 expressis verbis grants the right to participate in religious slaughter. Anne Peters noted that the reliance on imported meat - which is often reasoned with animal welfare concerns - is only an 'outsourcing' of animal cruelty. ${ }^{104}$

In conclusion, the main reason for such a difference between the outcome of the majority and the dissenting opinion is that the preceding is based on the premise that the Cha'are Shalom ve Tsedek was not a religious organisation according to French law However, considered from two standpoints, namely that the Cha'are Shalom ve Tsedek was a religious organization. The first premise has two logical consequences. First, the state could not infringe on Article 9 of the European Convention granting religious freedom, since the restriction - in the interpretation of the state's representative - was related to economic activity. Second, the Cha'are Shalom ve Tsedek - as a non-religious association - was not in an analogous situation with the ACIP or with the Muslim religious associations that are cited in the case. Thus, infringement of Article 14 could not have occurred.

99 | ECtHR, Swedish Engine Driver's Union v. Sweden, Judgment of 6 February 1976 Series A, para. 46.

100 | ECtHR, Cha'are Shalom case, Joint Dissenting Opinion, para. 2.

101 | Benyusz, Pék and Marinkás, 2020, p. 161.

102 | ECtHR, Cha'are Shalom case, paras. 82.

103 | ECtHR, Cha'are Shalom case, paras. 80-82.

104 | Peters, 2019, p. 291. 


\section{2.3. The pre-2020 case law of the ECJ on religious slaughter}

Before interpreting the case law of the ECJ, two points should be emphasized. First, the EU legislature - based on the scientific arguments introduced in section 1.3 - decided that, as a rule, slaughter shall be conducted only with prior stunning. Thus, ritual slaughter without prior stunning constitutes an exemption based on the regulation. Second, animal welfare is not a general principle of EU law, ${ }^{105}$ but an accepted value and public interest to be promoted and fostered based on the case law of the ECJ. ${ }^{106}$ The Court firmly stuck to this interpretation even after Article 13 of the Treaty on the Functioning of the European Union (TFEU) ${ }^{107}$ was introduced. ${ }^{108}$ Therefore, Micaela Lottini and Michele Giannino argue that, despite the introduction of Article 13 into the TFEU under EU law, animals seem to be attributed a dual status: on the one hand, they are qualified as 'sentient beings' and, accordingly, they are awarded a (limited) legal protection. On the other hand, animals are considered as 'products' or more precisely goods, because they can be valued in money and capable of forming the subject of commercial transactions. ${ }^{109}$ - It is worth comparing this with the Hungarian dogmatic theory on animals. ${ }^{110}$

In the C-426/16 Liga van Moskeeë ${ }^{111}$ case, the ECJ interpreted the freedom of religion by analysing Article 10 of the EU Charter on religious freedom, and the provisions of Article 13 of the TFEU on animal welfare requirements, particularly, to religious rites - more precisely, the so-called Eid al-Adha, the Muslim Feast of Sacrifice - related to Article 4 of the Regulation.

The domestic court raised the following question:

'Is Article 4(4) of [Regulation No 1099/2009], read in conjunction with Article 2(k) thereof, invalid due to the infringement of Article 9 of [the ECHR], Article 10 of the [Charter] and/or Article 13 [TFEU], in that it provides that animals may be slaughtered in accordance with special methods required by religious rites without being stunned only if such slaughter takes place in a slaughterhouse falling within the scope of [Regulation No 853/2004], whereas there is insufficient capacity in the Vlaams Gewest (Flemish Region) to meet the annual demand for the ritual slaughter of unstunned animals on the occasion of the ... Feast of Sacrifice, and the costs of converting temporary slaughter establishments, approved and monitored by the authorities, into slaughterhouses falling within the scope of [Regulation No 853/2004], do not appear relevant to achieving the objectives pursued of animal welfare and public health and do not appear proportionate thereto?'112

105 | C-189/01, Jippes case, Judgment of the Court, 12 July 2001

106 | C-592/14, European Federation for Cosmetic Ingredients v. Secretary of State for Business, Innovation and Skills. Opinion of Advocate General Michal Bobek, 17 March 2016, paras. 20-21; C 355/11, G. Brouwer case, Judgment of the Court (Sixth Chamber) of 14 June 2012

107 | Consolidated version of the Treaty on the Functioning of the European Union (OJ C 326, 26.10.2012, pp. 47- 390)

108 | Lottini and Giannino, 2019, pp. 502-511

109 | Sowery, 2018, pp. 58-59; See also: Geiger, Khan and Kotzur, 2015, p. 225.

110 | Based on 5:14 (3) of the Hungarian Civil Code (Act V of 2013) the animals are things from a legal perspective. 'The provisions pertaining to things shall apply to animals in accordance with the statutory provisions laying down derogations consistent with their natural characteristics.' The theoretical background is elaborated on in: Szilágyi, 2018, pp. 129-130.

111 | C-426/16, Liga van Moskeeën en Islamitische Organisaties Provincie Antwerpen, VZW and Others v Vlaams Gewest, Judgment of the Grand Chamber, 29 May 2018.

112 | Ibid, para. 26. 


\section{\begin{tabular}{l|l}
70 & LAW, IDENTITY AND VALUES \\
$2 \mid 2021$
\end{tabular}}

Advocate General Nils Wahl's opinion ${ }^{113}$ and the ECJ's judgment echoed the view that '[...] the concept of 'religious rite' [...] is defined in Article 2(g) of the Regulation as a series of acts related to the slaughter of animals and prescribed by a religion.' 114 Thus 'it falls within the scope of Article 10 (1) of the Charter.' ${ }^{115}$ However, as the Advocate General stated that I do not think it desirable for the Court to address the question of whether the ritual slaughter must, from a theological standpoint, necessarily be carried out'. The ECJ approved the opinion of the Advocate General. ${ }^{116}$ Considering the abovementioned arguments, the ECJ placed the case in an economic context. Furthermore, the determining argument of the Advocate General was that the reluctance of the applicants of the base case to assume the sunk costs of creating temporary slaughterhouses that meet public health requirements to meet the temporary increase in demand is not capable of affecting the validity of Article 4 (4) of the Regulation. ${ }^{117}$ Thus, the ECJ concluded as follows:

'[the] examination of the question did not disclose any issues capable of affecting the validity of Article 4(4) of Council Regulation (EC) No 1099/2009 of September 24, 2009, on the protection of animals at the time of killing, read together with Article 2(k) thereof, with regard to Article 10 of the Charter of Fundamental Rights of the European Union and Article 13 TFEU.'118

Anne Peters examined the Liga van Moskeeën decision of the ECJ and provided a thorough analysis. ${ }^{119}$ While she agrees with the outcome of the judgment, she criticises the ECJ for failing to consider the rights of religious minorities more broadly - including a more thorough analysis of the theological necessity of the ritual slaughter during the Feast of Sacrifice - and for not addressing the animal welfare point sufficiently. As she highlights, contrary to the ECJ's firm standpoint in this regard, even if the member state's regulation is neutral, it might deploy a disproportionate negative impact on particular religious groups. ${ }^{120}$ However, as a result of her examinations, she dismisses every argument that proves the existence of indirect discrimination. First of all she argues that - despite the differing context ${ }^{121}$-, the ECtHR's remarks in the Cha'are Shalom ve Tsedek may be applied in the present case, namely that the right to freedom of religion 'cannot extend to the right to take part in person in the performance of ritual slaughter [...].' Then Peters examines some of the key allegations of the Advocate General and the Court respectively. The Advocate General argued that the requirement of using only approved slaughterhouses

113 | C-426/16, Liga van Moskeeën en Islamitische Organisaties Provincie Antwerpen, VZW and Others v Vlaams Gewest, opinion of Advocate General Nils Wahl, 30 November 2017, para. 141.

114 | C-426/16, Liga van Moskeeën case, judgment, para. 47.

115 | Ibid, para. 49.

116 | C-426/16, Liga van Moskeeën case, judgment, paras. 45., 50-51.

117 | C-426/16, Liga van Moskeeën case, opinion of the advocate general, paras. 135-140.

118 | C-426/16, Liga van Moskeeën case, judgment, paras. 85.

119 | Peters, 2019, 269.; See furthermore: Peters, 2018

120 | Namely, the ECJ stated that '[...] the obligation to use an approved slaughterhouse, in accordance with the technical specifications required by Regulation No 853/2004, applies in a general and neutral manner to any party that organises slaughtering of animals and applies irrespective of any connection with a particular religion and thereby concerns in a non-discriminatory manner all producers of meat in the European Union.' - C-426/16, Liga van Moskeeën case, judgment, para. 61. 121 | The issue in Cha'are Shalom was rather the need for the ultraorthodox group to rely on slaughter performed by other licensed slaughterers for them according to their rites, without being able to examine in person whether their stricter rites had been duly observed. - Peters, 2019, p. 291. 
would not be proportionate to reach the objective of animal welfare; and therefore, would have to be qualified as an unjustified limitation and violation of the freedom of religion. ${ }^{122}$ Peters disagrees with this statement. One must reiterate that the Islamic religion lacks the dogmatic unity that characterise some other religions, such as the Catholic Church. As Peters states, religious opinion diverges whether slaughter is compulsory during the Feast of Sacrifice or not. Moreover, as a novel trend, young Muslims started to substitute the slaughter of animals with monetary donations. Similarly, there is disagreement among Muslim scholars regarding whether stunning animals is allowed or banned by the Muslim religion. Consequently, not every believer of the Islamic faith is concerned with the rules, and the restrictions imposed on their religion are bearable. She concludes that based on the aforementioned arguments the regulation of the member state is neither discriminative nor unproportioned. ${ }^{123}$ Even if Peters acknowledges that, as the Advocate General stated in his opinion:

'[...] some of the rules laid down in Annex III to Regulation No 853/2004, such as [...] the refrigerated storage of meat, may, [...] prove superfluous [...] inasmuch as [...] the meat from them will, in principle, be given directly to the final consumer.'124

In the C-497/17 Euvre d'assistance aux betes d'abattoirs case, the ECJ had to answer whether '[it is allowed for the national legislature to prohibit] the use of the European 'organic farming' label in relation to products derived from animals which have been slaughtered in accordance with religious rites without first being stunned [...]?'125 Special attention must be paid to the fact that these practices '[do not] respect high animal welfare standards' 126 Advocate General Nils Wahl in his opinion ${ }^{127}$ reiterated that, while Council Regulation on Organic Production and Labelling ${ }^{128}$ expressly bans certain practices, it does not require prior stunning. In other words, there is no outright ban on issuing organic labels on products from animals subjected to ritual slaughter. The Advocate General further argues that pre-stunning may prove unnecessary for satisfying the principle of protecting animal welfare: 'I do not think that the principle of prior stunning laid down in Regulation No 1099/2009 leads to the conclusion that the requirement of 'high animal welfare standards' necessarily means that slaughter is to take place with prior stunning.' ${ }^{129}$ The ECJ took the opposite view. The Court argued ${ }^{130}$ that EU law grants the right to conduct ritual slaughter without prior stunning, provided that certain legal requirements are obeyed. This constitutes sufficient protection to the right to religious

122 | C-426/16, Liga van Moskeeën case, opinion of the advocate general, paras 98-128., 91., 97., 133.

123 | Peters, 2019, pp. 292-294.

124 | C-426/16, Liga van Moskeeën case, opinion of the advocate general, para. 127.

125 | C-497/17, Euvre d'assistance aux bêtes d'abattoirs case, Judgment of the Grand Chamber, 26 Februar 2019, paras. 33.

126 | C-497/17, Euvre d'assistance aux bêtes d'abattoirs case, judgment, para. 36.

127 | C-497/17, Euvre d'assistance aux bêtes d'abattoirs case, opinion of advocate general Nils Wahl, 20 September 2018

128 | Council Regulation (EC) No 834/2007 of 28 June 2007 on organic production and labelling of organic products and repealing Regulation (EEC) No 2092/91 (OJ L 189, 20.7.2007, pp. 1-23)

129 | C-497/17 sz. Euvre d'assistance case, opinion of the advocate general, para. 83.

130 | C-497/17 sz. Euvre d'assistance case, judgment, paras. 36., 45., 48., 49., 52. 
freedom. The latter right cannot serve as grounds for claims to use organic labels on meat products that do not meet animal welfare considerations. ${ }^{131}$ As the ECJ argued that:

'[...] scientific studies have shown that pre-stunning is a technique that compromises animal welfare the least at the time of killing [...] the particular methods of slaughter prescribed by religious rites that are carried out without pre-stunning and that are permitted by [the Regulation] are not tantamount, in terms of ensuring a high level of animal welfare at the time of killing, to slaughter with pre-stunning [...]'.132

Micaela Lottini and Michele Giannino argue that the Advocate General took a more flexible and business-friendly position than the Court. While they praise the willingness of the ECJ to emphasize animal welfare concerns, they argue that the decision may adversely impact producers of halal or kosher food. ${ }^{133}$

\section{| 2.4. A short excursus to the jurisprudence of some selected national constitu- tional courts}

First, this section makes an excursus to the so-called Schächten-case of the German Federal Constitutional Court (Bundesverfassungsgericht, BverfG), the constitutional court that can be regarded as quasi-primus inter pares ${ }^{134}$ among European constitutional courts - which in the aforementioned judgment from $2002^{135}$ stressed - per its well-established case law ${ }^{136}$ - the importance of balancing the concurring rights and interests, in this particular case, the individual's right to religious freedom and personal development versus the interest of the public. As elaborated in section 1, during the last decades of the $19^{\text {th }}$ century and the first part of the $20^{\text {th }}$ century, several states of Germany imposed a ban on shechita. An ideologically motivated federal ban was imposed after the Nazis rose to power. After WWII, ritual slaughter was tacitly permitted until 1986, ${ }^{137}$ when the legislature ruled that warm-blooded animals should not be slaughtered without prior stunning. As an exemption, ritual slaughter was allowed, provided that the competent authority granted a license. The BverfG in its aforementioned judgment analysed the provisions of the 1986 act on animal protection and the license through the spectacles of Articles 4 (1) (2) and 2 (1) of the Basic Law of Germany (Grundgesetz, GG), ${ }^{138}$ granting the right to freedom of religion and conscience, and the right to personal development, respectively. ${ }^{139}$ As the

131 It is worth mentioning that a petition was submitted to the European Parliament's Committee on Petitions with the aim of repealing Article 4 (4). The petition was rejected since - as the Committee argued - the Regulation together with other sources of law of the Union strikes a fair balance between human welfare considerations and the right to religious freedom. See: Petition 1063/2014 by Marta Poschlod on the ban on ritual slaughter

132 | C-497/17, Euvre d'assistance case, judgment, paras. 47., 50.

133 | Lottini - Giannino, 2019, pp. 502-511.

134 | Editorial Comments, 2020, pp. 965-978; See furthermore the concurring opinion of Juhász Imre to decision No. 22/2016 (XII.5.) of the Hungarian Constitutional Court

135 | BVerfG, Urteil des Ersten Senats vom 15. Januar 2002 - 1 BvR 1783/99 -, Rn. 1-61, More on the case: Silver, 2011, pp. 671-672.

136 | See: Bomhoff, 2013, p. 280.

137 | Tierschutzgesetzes vom 12. August 1986 (BGBl I S. 1309)

138 | Grundgesetz für die Bundesrepublik Deutschland (1949)

139 | It has to be noted that the applicant also claimed that his right to choose his profession freely (GG Article 12 (1)) was also violated. The BVerfG dismissed this claim since, the applicant was not a German citizen - 1BvR 1783/99, para. 3. 
BverfG stated, the prevalence of the rights of animals and their welfare considerations can be regarded as public interest, which enjoys the support of society's majority. The licensing procedure aims to ensure that ritual slaughter, which is conducted without prior stunning, remains exceptional and well-inspected. ${ }^{140}$ The latter are served by regular examinations of the facilities and personnel working there. As the BVerfG noted, the rules on licensing cannot be considered unconstitutional because the examination conducted by the authority focuses on the prevalence of the requirements laid down in law, and does not entail any evaluation of the religious prescriptions. Nevertheless, when it comes to the case at hand, both the authority - which denied granting the license - and the courts deciding on the appeal, failed to properly interpret the provisions of the GG and the law. In its decision, ${ }^{141}$ the Federal Administrative Court (Bundesverwaltungsgericht, BVerwG) used arguments that were based on the examination and evaluation of certain religious practices, and their necessity from a theological standpoint, that is, whether there is a ban in the Islamic religious scriptures on consuming meat of pre-stunned animals, and whether it is compulsory to consume meat at all. As the BVerwG noted regarding the latter: 'The adherents of such a religion can change over to food of vegetable origin or to fish [...] doing without meat, however, does, according to the Court, not constitute an unreasonable restriction of the freedom to develop one's personality.'142 The BVerfG dismissed this argument and - just like the ECJ/ECtHR in the aforementioned cases -, dismissed the concept that a non-religious court may have any jurisdiction to decide on religious issues and referred the case back to the administrative court. ${ }^{143}$

The second excursus is made to the ritual slaughter case of the Polish Constitutional Court (Trybunat Konstytucyjny). As mentioned previously, shechita was banned in Poland in 1939, even if the 1939 amendment of the 1936 Act never came into force due to a procedural error. The 1936 act was formally repealed in $1997^{144}$ by the 1997 Act on Animal Protection (Ustawa o ochronie zwierzat), ${ }^{145}$ which again allowed exceptions for slaughter manners of specific religious groups, until 2002, when the amendment of the act cancelled the exception for ritual slaughter. However, just like in the case of the 1936 Act, ritual slaughter was allowed based on a directive issued in 2004 by the Minister of Agriculture and Rural Development. On 27 November 2012 - proceeding on the motion of the Public General-Prosecutor (Prokurator Generalny), supported by animal rights organizations -, the Polish Constitutional Court quashed the directive because the ordinance was issued without due statutory authorization. Consequently, a full-fledged prohibition of religious slaughter without stunning took effect in Poland. ${ }^{146}$

In August 2013 the Association of Jewish Religious Communities ${ }^{147}$ (Związku Gmin Wyznaniowych Żydowskich w Rzeczypospolitej Polskiej) filed an application to the Constitutional Tribunal of Poland to examine the compliance of the provisions of the Animal Protection Act with the Constitution of the Republic of Poland (Konstytucja

140 | 1 BvR 1783/99, paras. 40-41., 45-46., 57-58.

141 | BVerwG, 15.06.1995 - 3 C 31.93

142 | 1 BvR 1783/99, para. 10.

143 | 1 BvR 1783/99, para. 60.

144 | Journal of Laws (Dz. U.) no. 60 item 369 with amendment

145 | The Animal Protection Act, Journal of Laws (Dz. U.) consolidated text from 2019 item 122.

146 | Skóra, 2019, pp. 289-290.

147 | The President of the Muslim Religious Union in Poland (Muzułmański Związek Religijny),

Tomasz Miśkiewicz, was also present at the Court as an observer. 


\section{LAW, IDENTITY AND VALUES \\ $2 \mid 2021$}

Rzeczypospolitej Polskie) ${ }^{148}$ and the EU Charter. The Court delivered its decision on the $10^{\text {th }}$ December 2014. ${ }^{149}$ However, in the case of religious freedom, there were other things at stake: in 2012, the Polish meat industry exported an estimated 200,000 tons of kosher and halal meat, amounting to approximately 329 million USD. Some authors argue that the economic interests tainted the majority decision, and the constitutional principles had to 'yield' before the economic interests of the country. This, of course, was not written by the majority. According to Judge Sławomira Wronkowska-Jaśkiewicz, ${ }^{150}$ the Constitutional Court wrongly went beyond the applicants' claim and extended the protection of religious freedom as granted by Article 53 of the Polish Constitution for those carrying out merely economic activity. Her argument is supported by the dissenting opinions ${ }^{151}$ of judges Teresa Liszcz, Piotr Tuleja, and Wojciech Hermeliński - and certain authors ${ }^{152}-$ who sharply criticised the majority judgment for going beyond the claimants' demands to meet the economic interests. Judge Hermeliński in his dissenting opinion ${ }^{153}$ even provided a draft text that, in his view, the Court should have adopted to narrow the exemption to those affected - namely, those who live in Poland ${ }^{154}$ - to serve the prevalence of religious freedom. His suggestion reads as follows:

'[the Polish law] - insofar as it does not permit subjecting animals to particular methods of slaughter prescribed by Judaism (the so-called shechita) to meet the needs of the followers of that religion in Poland ${ }^{155}$ - is inconsistent with [the Constitution].'156

The decision of the Polish Constitutional Court received further criticism from the dissenting judges - Teresa Liszcz and Mirosław Wojciech Granat ${ }^{157}$ - and scholars for the way the majority decision of the court elaborated on the moral standards. ${ }^{158}$ Aleksandra Gliszczytiska-Grabias and Wojciech Sadurski criticised the Constitutional Court ${ }^{159}$ for

148 | Ratified: 2 April 1997.

149 | Polish Constitutional Court, Judgment of 10 December 2014 Ref. No. K 52/13 (/s/k-5213). Official English translation. [Online]. Available at: https://trybunal.gov.pl/en/hearings/judgments/ art/7276-uboj-rytualny/ (Accessed: 24 September 2021).

150 | Dissenting Opinion of Judge Sławomira Wronkowska-Jaśkiewicz to the judgment of the Constitutional Tribunal of 10 December 2014, ref. no. K 52/13.

151 | Dissenting Opinion of Judge Teresa Liszcz to the judgment of the Constitutional Tribunal of 10 December 2014, ref. no. K 52/13; Dissenting Opinion of Judge Piotr Tuleja to the judgment of the Constitutional Tribunal of 10 December 2014, ref. no. K 52/13.

152 | Gliszczytiska-Grabias and Sadurski, 2015, pp. 604-605., 608.; See also: Skóra i.m. p. 294.

153 | Dissenting Opinion of Judge Wojciech Hermeliński to the judgment of the Constitutional Tribunal of 10 December 2014, Ref. No. K 52/13.

154 | Based on official statistics some 100000 Jews live in Poland, however most of them are not conscious of his/her origin or does not hold religious laws. See: Yardena ScHWARTZ, 40 Miles from Auschwitz, Poland's Jewish Community is Beginning to Thrive. Time, February 27, 2019. [Online]. Available: https://time.com/5534494/poland-jews-rebirth-anti-semitism/ (Accessed : 24 September 2021).

155 | Italicising added by the author.

156 | Dissenting Opinion of Judge Wojciech Hermeliński to the judgment of the Constitutional Tribunal of 10 December 2014, Ref. No. K 52/13.

157 | Dissenting Opinion of Judge Mirosław Granat to the judgment of the Constitutional Tribunal of 10 December 2014, ref. no. K 52/13.

158 | Polish Constitutional Court, Judgment of 10 December 2014, paras. 7.2., 8.2.2.

159 | Gliszczytiska-Grabias and Sadurski, 2015, pp. 607-608. 
building the notion of public morality exclusively on the [Christian] ${ }^{160}$ morality of the majority. ${ }^{161}$ In their view, it would result in the 'double counting' of religious freedom: first, as an independent constitutional principle, and second, as an ingredient of 'public morals. ${ }^{162}$ Instead, as Anna Śledzińska-Simon argues, 'morality' should be a set of rules, norms, values, views, and models of conduct, which are generally acceptable in a democratic society. She concludes that public morality may justify only such limitations of constitutional rights and freedoms that would be considered as generally harmful, rather than harmful, in the perception of the majority. ${ }^{163}$ Criticisms against the Constitutional Court's decision were also articulated to deny the constitutional status of animal welfare. ${ }^{164}$

\section{The newest case of the ECJ related to freedom of religion: The C-336/19 Centraal Israëlitisch Consistorie van België case}

The importance of the case - as it was emphasized by Advocate General Hogan ${ }^{165}$ lies in the fact that (i) it was the first precedent to analyse Article 26 (2/1) point ' $c$ ' of the Regulation and decides on its validity. Furthermore, (ii) the Court had to answer whether the abovementioned Article of the Regulation permits Member States to adopt rules that restrict religious slaughter without prior stunning 'with a view to promoting animal welfare', contrary to Article 4 (4).

The base case originated from the constitutional review of the Decree (hereafter: contested decree) on the modification of the Act 1986 'On the Protection and Welfare of Animals, Regarding Permitted Methods of Slaughtering Animals'166 (Flemish Animal Protection Act) by the Grondwettelijk Hof, the Belgian Constitutional Court. The decree was enacted on 7 July 2017 and entered into force on 1 January 2019.

160 Interpreting addition by the author.

161 | It is worth keeping in mind that some $86 \%$ of the Polish population is Roman Catholic. This proportion is higher than in Italy (67 \%). See: Rocznik Statystyczny - Rzeczypospolitej Polskiej (Statistical Yearbook of the Republic of Poland) https:/stat.gov.pl/en/topics/statistical-yearbooks/ statistical-yearbooks/statistical-yearbook-of-the-republic-of-poland-2019,2,21.html [2021. 08. 22.]; See also: US Department of State, 2019 Report on International Religious Freedom: Italy. [Online]. Available at: https://www.state.gov/reports/2019-report-on-international-religiousfreedom/italy/ (Accessed: 24 September 2021).

162 | In their view this is also the result of the Polish Constitutional Court's consistent failure to protect the secularity of the state.

163 | Śledzińska-Simon, 2015.

164 | It is worth mentioning that the Austrian Constitutional Court (Verfassungsgerichtshof) in its 1998 decision also denied the constitutional status of animal protection. The Court emphasized that: 'it does not overlook the fact that a change in values has taken place in recent decades [...] animal protection embodies a widely recognised and significant public interest. However, animal protection [...] does not yet have a decisive weight compared to the right to freedom of religion.' See: Verfassungsgerichtshof (B3028/97) 17.12.1998 - (ECLI:AT:VFGH:1998:B3028.1997), para. 2.7.1.

165 | C-336/19, Centraal Israëlitisch Consistorie van België case, opinion of the advocate general, para.13.

166 | Wet betreffende de bescherming en het welzijn der dierennek (Belgisch Staatsblad, 3 December 1986. p. 16382) 
Before the modifications entered into force, Article 16 (1) of the Flemish Animal Protection Act required prior stunning of the animal, except for the case of vis-maior, when the animal was permitted to be killed by causing less pain. Paragraph (2) of the Article granted an exemption for slaughter that was conducted for religious purposes. The abovementioned modification reduces this exemption. According to Article 15 (2) of the modified act, if the animals are slaughtered according to special methods required for religious rites, the stunning must be reversible and the animal's death must not be caused by stunning. '167

The aims of the legislature shall be examined based on the preparatory materials of the Flemish regulation. These documents make it clear that the reform was aimed at ensuring animal welfare considerations and the prevalence of religious freedom at the same time. Having considered the scientific facts and religious prescriptions, the legislature chose electronarcosis as the statutory method for stunning, since it does not cause irreversible harm to the animal. Contrarily, its effect is completely reversible, the animal regains consciousness if the cut is not administered. If the cut is still performed, the animal dies of bleeding, the effectiveness of which is not decreased by the electronarcosis.

The arguments of the applicants of the base case before the Grondwettelijk Hof is introduced in five points by the Advocate General. ${ }^{168}$

First, 'Infringement of [the Regulation] read in conjunction with the principle of equality and non-discrimination, in that Jewish and Muslim believers are being deprived of the guarantee contained in Article 4(4) of [the Regulation] to the effect that ritual slaughter cannot be made subject to the requirement of prior stunning, and in that the contested decree, contrary to Article 26(2) of the aforementioned regulation, was allegedly not notified to the European Commission in time.' ${ }^{169}$

Second, 'Infringement of freedom of religion, by making it impossible for Jewish and Muslim believers, on the one hand, to slaughter animals in accordance with the rules of their religion and, on the other hand, to obtain meat from animals slaughtered in accordance with those religious rules. ${ }^{170}$

Third, 'Infringement of the principle of separation of Church and State, because the provisions of the contested decree allegedly prescribe the manner in which a religious rite is to be carried out.' 171

Fourth, 'Infringement of the right to work and to the free choice of occupation, freedom to conduct a business and the free movement of goods and services, because it is impossible for religious butchers to practise their occupation [...] and because it distorts competition between slaughterhouses [under the jurisdiction of the domestic law] or in another Member State of the European Union where the slaughter of animals without stunning is permitted.' ${ }^{172}$

Fifth, 'Jewish and Muslim believers are treated, without reasonable justification, in the same way as people who are not subject to the specific dietary laws of a religion; the people who kill

167 | C-336/19, Centraal Israëlitisch Consistorie van België case, judgment, paras. 11-12.

168 | C-336/19, Centraal Israëlitisch Consistorie van België case, opinion of the advocate general, para. 34

169 | Ibid, para. 34.

170 | Ibid, para. 34.

171 I Ibid, para. 34.

172 | Ibid, para. 34. 
animals while hunting or fishing or controlling harmful organisms, on the one hand, and the people who kill animals according to special slaughter methods prescribed by the customs of religious worship, ${ }^{173}$ on the other hand, are treated differently without reasonable justification, and Jewish believers, on the one hand, and Muslim believers, on the other hand, are treated in the same way without reasonable justification.' ${ }^{174}$

The Flemish and the Walloon governments took an opposite view, where they argued that Article 26 (2/1) point ' $c$ ' of the Regulation expressly permits Member States to adopt rules that restrict religious slaughter without prior stunning, and 'with a view to promoting animal welfare,' contrary to Article 4 (4).

'In those circumstances the Grondwettelijk Hof [...] decided to stay the proceedings and to refer the following questions to the Court of Justice for a preliminary ruling: ${ }^{175}$

(1) Should point (c) of the first subparagraph of Article 26(2) of [Regulation No 1099/2009] be interpreted as meaning that member states are permitted, by way of derogation from [...] Article 4(4) of that regulation and with a view to promoting animal welfare, to adopt rules such as those contained in the decree [at issue in the main proceedings], rules which provide, on the one hand, for a prohibition on the slaughter of animals without stunning that also applies to the slaughter carried out in the context of a religious rite and, on the other hand, for an alternative stunning procedure for the slaughter carried out in the context of a religious rite, based on reversible stunning and on the requirement that the stunning should not result in the death of the animal? ${ }^{176}$

(2) If the first question referred for a preliminary ruling is to be answered in the affirmative, does point (c) of the first subparagraph of Article 26(2) of Regulation No 1099/2009, in the interpretation referred to in the first question, infringe Article 10(1) of the [Charter]? ${ }^{177}$

(3) If the first question referred for a preliminary ruling is to be answered in the affirmative, does point (c) of the first subparagraph of Article 26(2) read in conjunction with Article 4(4) of Regulation No 1099/2009, in the interpretation referred to in the first question, infringe Articles 20, 21 and 22 of the [Charter], since, in the case of the killing of animals by particular methods prescribed by religious rites, provision is only made for a conditional exception to the obligation to stun the animal (Article 4(4), read in conjunction with Article 26(2) [of that regulation]), whereas in the case of the killing of animals during hunting and fishing and during sporting and cultural events, for the reasons stated in the recitals of the regulation, the relevant provisions stipulate that those activities do not fall within the scope of the regulation, or are not subject to the obligation to stun the animal when it is killed (Article 1(1), second subparagraph, and Article 1(3) [of that regulation])?'178

In his opinion, the Advocate General analysed the first two questions and dispensed the third one by analysing it, per the Court's request. Having regarded the organic

173 | As it was already introduced in the first structural part of the current article, a similar reasoning emerged related to the exemption granted for the Sámi people by the Scandinavian countries. 174 | C-336/19, Centraal Israëlitisch Consistorie van België case, opinion of the advocate general, para. 34

175 | C-336/19, Centraal Israëlitisch Consistorie van België case, judgment, para. 32.

176 | C-336/19, Centraal Israëlitisch Consistorie van België case, judgment, para. 32.

177 | Ibid, para. 32.

178 | Ibid, para. 32. 
connection between the two, the Advocate General decided that he would answer the two questions together. ${ }^{179}$

In his preliminary remarks, the Advocate General made two important statements: (i) he refuted the applicants' allegations that the European Commission was not notified in due time. Furthermore, (ii) He reiterated his own opinion as Advocate General in the C-243/19 A. vs Veselibas Ministrija case ${ }^{180}$ and the case-law of the ECtHR, ${ }^{181}$ and concluded that 'a secular court cannot choose in relation to the matters of religious orthodoxy.' ${ }^{182} \mathrm{He}$ argued that:

'[It is] sufficient to say that there is a significant body of adherents to both the Muslim and Jewish faiths for whom the slaughter of animals without such stunning is regarded by them as an essential aspect of a necessary religious rite.' 183

The Advocate General first analysed Articles 4 (1) and (4) of the Regulation. Furthermore, he cited the case law of the ECJ. ${ }^{184}$ Reiterating the statements of the ECJ in the Liga van Moskeeën case, the Advocate General argues that according to the Court's case-law:

'It must be observed that the Charter uses the word 'religion' in a broad sense, covering both the forum internum that is the fact of having a belief, and the forum externum, that is the manifestation of religious faith in public.'185

Consequently, in the cited case, the ECJ concluded that the scope of Article10 (1) of the EU Charter covers the special slaughter methods, which are described in Article 4 (4) and should be interpreted as the manifestation of religious faith. However, the Court stated that having regarded Article 4 (1) of the Regulation, slaughter which falls under the scope of Article 4 (4) may be the subject of '[...] technical conditions or specifications that seek to minimize the suffering of animals at the time of killing and ensure the health of all consumers of meat which are neutral and non-discriminatory in their application [...].' ${ }^{186}$ That is to say: "[...] restrictions on the religious freedom may be imposed on the freedom to carry out slaughter without prior stunning for religious purposes to organise and manage that slaughter.'187 The decision of the court delivered in the Euvre d' assistance case conforms to the above-cited opinion of the Advocate General. Moreover, the Court stated that

179 | C-336/19, Centraal Israëlitisch Consistorie van België case, opinion of the advocate general, paras. $43 ., 45$.

180 | C-243/19, A v Veselības ministrija, opinion of Advocate General Gerard Hogan, 30 April 2020, para. 5.

$181 \mid$ |'...] the Court has held that the State's duty of neutrality and impartiality, as defined in its case-law [...] is incompatible with any power on the State's part to assess the legitimacy of religious beliefs' See: ECtHR, Vartic v. Romania, Judgment, 17 March 2014, para. 34.

182 | C-336/19, Centraal Israëlitisch Consistorie van België case, opinion of the advocate general, para. 47.

183 | C-336/19, Centraal Israëlitisch Consistorie van België case, opinion of the advocate general, para. 47.

184 | C-336/19, Centraal Israëlitisch Consistorie van België case, opinion of the advocate general, paras. 50-59. and the ECJ case-law cited there.

185 | Please find a detailed analysis on the difference between forum internum and externum in: Morini, 2010, pp. 628-630.

186 | C-426/16, Liga van Moskeeën case, opinion of the advocate general para. 58.

187 | C-426/16, Liga van Moskeeën case, opinion of the advocate general para. 58. 
'the derogation provided for by Article 4 (4) of Regulation No. 1099/2009 does not extend beyond what is strictly necessary to ensure observance of the freedom of religion.' ${ }^{188} \mathrm{~A}$ significant part ${ }^{189}$ of the opinion, which is worth highlighting, is that the Advocate General draws attention to the issues of interpreting the law because of the tension between the wording of Paragraphs (1) and (4) of Article 4 of the Regulation. While the former applies 'strict terms', the latter uses the expression '[...] animals subject to particular methods of slaughter prescribed by religious rites. ${ }^{190}$ As the Advocate General argues, this is in contrast with the lack of any concrete or specific limits to the derogation contained in Article 4(4), other than the requirement that the slaughter in question be prescribed by religious rites and take place in a slaughterhouse. ${ }^{\prime 19}$ In the course of examining the merits of the case, the second thoroughly analysed part was Article $26(2 / 1)$ point 'c' of the Regulation, which permits Member States to adopt rules that restrict religious slaughter without prior stunning 'with a view to promoting animal welfare' contrary to Article 4 (4). As the Advocate General reiterated: 'The general words of Article 26(2) cannot be read in such a manner as would take from the specific provisions of Article 4(4).'192 The Advocate General highlighted that a stricter national regulation maybe adopted, 'provided that the 'core' of the religious practice in question, namely ritual slaughter, is not encroached upon. ${ }^{193}$ Furthermore, he brings examples to the possible restrictions that conform to EU law, namely: (i) the requirement of the presence of a qualified veterinarian at all times during the ritual slaughter; (ii) requirement of the proper training of the person conducting that particular form of slaughter; and (iii) rules on the nature, size, and sharpness of the knife used, and the requirement of keeping a second knife at hand if the first one becomes damaged during slaughter. According to the Advocate General, the requirement of prior stunning should not be regarded as conforming to the Regulation. The logic of the opinion, which is clear and coherent until this point, seems to break down here. The Advocate General fails to provide reasoning behind his consideration of the domestic law, which prohibits the slaughter of animals without prior stunning, to be in contradiction with the EU law. ${ }^{194}$ Instead, the reader has to be satisfied with the Advocate General's opinion in paragraph 76: 'I do not consider it fruitful to speculate on which type of measures could lawfully be adopted by Member States [...]' and that 'It is not the role of the Court to give advisory opinions on the matter.'195 The latter projected the statement

188 | C-497/17, opinion of the advocate general, para. 59.

189 | C-336/19, Centraal Israëlitisch Consistorie van België case, opinion of the advocate general, paras. 60-65.

190 | C-336/19, Centraal Israëlitisch Consistorie van België case, opinion of the advocate general, para. 53.

191 | C-336/19, Centraal Israëlitisch Consistorie van België case, opinion of the advocate general, para. 61.

192 | C-336/19, Centraal Israëlitisch Consistorie van België case, opinion of the advocate general, para. 67.

193 | C-336/19, Centraal Israëlitisch Consistorie van België case, opinion of the advocate general, para. 72.

194 | On the other hand, he provides the Court with a rather detailed analysis regarding why the possibility of procuring meat without restriction is an insufficient guarantee of the right to religious freedom regardless what the majority of judges held in the ECtHR's Cha'are Shalom case. - See: C-336/19, Centraal Israëlitisch Consistorie van België case, opinion of the advocate general, paras. 82-87.

195 | C-336/19, Centraal Israëlitisch Consistorie van België case, opinion of the advocate general, para. 76. 
of the Advocate General in paragraph 47 of his opinion, namely 'a secular court cannot choose in relation to the matters of religious orthodoxy.' Summarising his thoughts, the Advocate General states in paragraph 76 of the opinion that: 'It is simply sufficient to say that this power does not extend as far as prohibiting ritual slaughter without stunning in the manner contemplated in the present proceedings by the Flemish legislature.'196

The author of the current article argues that the Advocate General simply swept away any scientific reasoning, introduced in the first section of the article which supports that slaughter with prior and reversible stunning is the best possible solution. What is worse, the Advocate General arbitrarily picked and arbitrarily evaluated the EU law. As the Eurogroup for Animals argues in its amicus curiae brief, ${ }^{197}$ the Advocate General failed to consider that the EU legislature intentionally executed only a partial harmonization regarding the rules on slaughtering animals. This is supported by Article 13 of the TFEU:

'[...] the Union and the Member States shall, since animals are sentient beings, pay full regard to the welfare requirements of animals, while respecting the legislative or administrative provisions and customs of the Member States relating in particular to religious rites, cultural traditions, and regional heritage.'198

Furthermore, recital (18) of the Regulation provides that a certain level of subsidiarity remains among the Member States regarding the rules on slaughtering of animals. According to Article 26 (2/1) point ' $c$ ' of the Regulation:

'Member States may adopt national rules aimed at ensuring more extensive protection of animals at the time of killing than those contained in this Regulation in relation to the following fields [...] the slaughtering and related operations of animals in accordance with Article 4(4).' ${ }^{\prime 99}$

Within the meaning of Article 2 point 'b' of the Regulation 'related operations' are '[...] means operations such as handling, lairaging, restraining, stunning and bleeding of animals taking place in the context and at the location where they are to be killed; [...]' 200

These shortcomings are particularly sore spots with special regard to the fact that, as the author already mentioned above, the opinion of the Advocate General otherwise contains valuable statements such as those on the inconsistencies of the Regulation's wording that have a detrimental effect on animal welfare considerations. Furthermore, as a positive aspect, the Advocate General realizes the provisions on the rights and duties of states arising from Article 13 of the TFEU. As the Advocate General wrote:

'In my view, Article 4 (1) of Regulation No. 1099/2009 is the cornerstone of that regulation and reflects and gives concrete expression to the clear obligation ${ }^{201}$ imposed by the first part of

196 | Ibid.

197 | Eurogroup for Animals, pp. 4-5.

198 | TFEU Article 13.

199 | Regulation No.1099/2009, Article 4 (4).

200 | Regulation No. 1099/2009, Article 2 point 'b'.

201 | Italicising added by the author. 
Article 13 TFEU on both the Union and the Member States to pay full regard to the welfare requirements of animals, which are sentient beings [...].'202

Sadly, he drew false conclusions. He proposed that the first and second questions shall be answered as follows:

'Point (c) of the first subparagraph of Article 26(2) of Council Regulation(EC) No 1099/2009 of 24 September 2009, on the protection of animals at the time of killing, read together with Article 4(1) and 4(4) thereof, and having regard to Article 10 of the Charter of Fundamental Rights of the European Union and Article 13 TFEU, must be interpreted as meaning that Member States are not permitted to adopt rules which provide, on the one hand, for a prohibition of the slaughter of animals without stunning that also applies to the slaughter carried out in the context of a religious rite and, on the other hand, for an alternative stunning procedure for the slaughter carried out in the context of a religious rite, based on reversible stunning and on condition that the stunning should not result in the death of the animal.'203

The ECJ came to the opposite conclusion. Namely, the Court stated that:

'Point (c) of the first subparagraph of Article 26 (2) of Council Regulation (EC) No 1099/2009 of 24 September 2009, on the protection of animals at the time of killing, read in the light of Article 13 TFEU and Article 10 (1) of the Charter of Fundamental Rights of the European Union, must be interpreted as not precluding legislation of a member state that requires, in the context of ritual slaughter, a reversible stunning procedure which cannot result in the animal's death.'204

Having regarded that this difference arise from the differing evaluation of the very same facts and legal provisions, the author only elaborates on the differences in the evaluation.

One of the differences is that the ECJ put greater emphasis on the prevalence of Article 52 (1) and (3) of the EU Charter read in conjunction with Article 13 of the TFEU. The ECJ applied the Gebhard-test ${ }^{205}$. As the Court pointed out:

(i) '[...] the limitation on the exercise of the right to the freedom to manifest religion identified in paragraph 55 above is provided for by law, within the meaning of Article 52 (1) of the Charter'; (ii) '[...] national legislation which lays down the obligation to stun the animal beforehand during ritual slaughter, while stipulating that that stunning should be reversible and not cause the animal's death, respects the essence of Article 10 of the Charter, since, according to the information in the documents before the Court, set out in paragraph 54 above, the interference resulting from such legislation is limited to one aspect of the specific ritual act of slaughter, and that act of slaughter is not, by contrast, prohibited as such.' (iii) The ECJ took the view that 'it is apparent [...] that the Flemish legislature intended to promote animal welfare [and to] to eliminate all avoidable animal

202 | C-336/19, Centraal Israëlitisch Consistorie van België case, opinion of the advocate general, para. 52.

203 | C-336/19, Centraal Israëlitisch Consistorie van België case, opinion of the advocate general, para. 88.

204 | C-336/19, Centraal Israëlitisch Consistorie van België case, judgement, para. 96.

205 | C-55/94, Gebhard-case, judgment, 30 November 1995, para. 37. 
suffering.' [...] 'It is clear both from the case-law of the Court ${ }^{206}$ [...] and from Article 13 TFEU that the protection of animal welfare is an objective of general interest recognised by the European Union'. ${ }^{207}$ (iv) '[...] it should be borne in mind that [...] the corresponding rights of the ECHR [must be taken into account] for the purpose of interpreting the Charter, as the minimum threshold of protection [...]'208

As the ECJ pointed out, based on the case-law of the ECtHR ${ }^{209}$ the state - as a rule has a wide margin of appreciation when it acts within the scope of Article 9 of the ECtHR. The width of the margin of appreciation on the EU level also stems from the fact that there is no consensus on the subject matter covered by the Regulation. The EU legislature intentionally stated in recital (18) that Member States shall keep a 'certain level of subsidiarity.' Similarly, both the difference between Paragraph (1) and (4) - which was expressly highlighted by the Advocate General - and the wording of Article 26 (2/1) point ' $c$ ' that permits Member States to adopt differentiated rules serves the handling of these differences. ${ }^{210}$ (iv/b) '[...] like the ECHR, the Charter is a living instrument which must be interpreted in the light of present-day conditions and of the ideas prevailing in democratic States today [...] with the result that regard must be had to changes in values and ideas, both in terms of society and legislation, in the Member States. Animal welfare, as a value to which contemporary democratic societies have attached increasing importance for several years. ${ }^{211}$ Of course, different societies evaluate human rights protection considerations and religious customs differently. As the ECJ noted, however, '[...] the Flemish legislature was entitled to adopt, following a wide-ranging debate organized at the level of the Flemish Region, the decree at issue in the main proceedings' [...]. ${ }^{212}$ Based on the current stand of sciences: A scientific consensus has emerged that prior stunning is the optimal means of reducing the animal's suffering at the time of killing'. ${ }^{213}$ The latter statement is supported by the scientific opinions of the EFSA cited in recital (6) of the Regulation. ${ }^{214}$ As the Court pointed out, the Flemish legislature weighted the animal protection considerations and the requirement of religious freedom's prevalence in a proper manner, when it prescribed a method of stunning that is first of all totally reversible - namely, it does not cause the death of the animal, and second, it does not have a detrimental effect on the draining-out process. The Flemish decree - per Article 26 (4) of the Regulation -'...] neither prohibits nor impedes the putting into circulation, within the territory in which it applies, of products of animal origin derived from animals which have undergone ritual slaughter, without prior stunning, in another Member State.'215 The ECJ - contrary to the opinion of the Advocate General - hereby dispenses with making a reference to the ECtHR's Cha'are Shalom case, where judges came - though not a unanimous - conclusion that 'the right to freedom of religion guaranteed by Article 9 of the Convention cannot

206 | See the cases cited at para. 63 of the judgment delivered in the C-336/19, Centraal Israëlitisch Consistorie van België case.

207 | C-336/19, Centraal Israëlitisch Consistorie van België case, judgement, paras. 62-63.

208 | C-336/19, Centraal Israëlitisch Consistorie van België case, judgement, para. 56.

209 | See: ECtHR, SAS v. France, Judgment, 1 July 2014

210 | C-336/19, Centraal Israëlitisch Consistorie van België case, judgment, paras. 64-71.

211 | C-336/19, Centraal Israëlitisch Consistorie van België case, judgment, para. 77.

212 | C-336/19, Centraal Israëlitisch Consistorie van België case, judgment, para. 79.

213 | C-336/19, Centraal Israëlitisch Consistorie van België case, judgment, para. 72.

214 | C-336/19, Centraal Israëlitisch Consistorie van België case, judgment, paras. 72-76.

215 | C-336/19, Centraal Israëlitisch Consistorie van België case, judgment, para. 78. 
extend to the right to take part in person in the performance of ritual slaughter [...].'216 Thus, as far as the believers of a certain faith do not deny the possibility of procuring and consuming meat of animals slaughtered according to their religious beliefs, there is no violation of Article 9 of the European Convention. In the author's view, the fact that the Court - contrary to the opinion of the Advocate General ${ }^{217}$ - did not pay attention to the possible halts in the supply chains can serve as grounds to criticize the ECJ's judgment. Possible halts may include either proposed or actually imposed export bans on kosher meat products ${ }^{218}$ or vis-maior events with unforeseen consequences, such as the COVID19 pandemic. ${ }^{219}$ By its third question - which was not analysed by the Advocate General upon request of the court - the referring court 'in essence raises the validity of point (c) of the first subparagraph of Article 26 (2) [the Regulation] in light of the principles of equality, non-discrimination, and cultural, religious, and linguistic diversity, as guaranteed by Articles 20, 21, and 22 of the [EU] Charter, respectively.'220 The applicants of the base case provided a reasoning, ${ }^{221}$ namely, 'the applicants observe that the above decree, adopted pursuant to that regulation, treats differently, without any reasonable justification, those who kill animals while hunting or fishing, or in the context of pest control and those who kill animals in accordance with particular methods of slaughter prescribed by a religious rite'.222

The ECJ, citing its case-law reiterated that 'the prohibition on discrimination is merely a specific expression of the general principle of equality which is one of the fundamental principles of EU law, and that that principle requires that comparable situations must not be treated differently and that different situations must not be treated in the same way unless such treatment is objectively justified.'223 The Court examined Article 1 (3) of the Regulation, which provides that 'This Regulation shall not apply [...] where animals are killed: during hunting or recreational fishing activities; during cultural or sporting events [...]'224

The ECJ made four statements about this. The author only introduces the first two because they are relevant and can be regarded as 'clinchers'. The first statement of the

216 | ECtHR, Cha'are Shalom case, judgment, paras. 82.

217 | See paras 82-87 of the Advocate General's opinion in the C-336/19 Centraal Israëlitisch Consistorie van België case.

218 | Kayleigh Lewis: Netherlands bans export of kosher and halal meat to 'minimise' negative effects on animal welfare Martijn van Dam, Netherlands' junior minister for economic affairs, hopes new measures minimising 'ritual slaughter' will reduce animal suffering. Independent (18 February 2016) [Online]. Available at: https://www.independent.co.uk/news/world/europe/netherlandsbans-export-kosher-and-halal-meat-minimise-negative-effects-animal-welfare-a6881406. html (Accessed: 24 September 2021); Aaron Reich: Poland postpones kosher meat export ban till 2025. The Jerusalem Post (14 October 2020) [Online]. Available at: https://www.jpost.com/diaspora/ poland-postpones-kosher-meat-export-ban-till-2025-645717 (Accessed: 24 September 2021).

219 | Marinkás 2021a, pp. 5-6.; See furthermore: Ungvári and Hojnyák, 2020, pp. 122-138.; The effects of the COVID-19 on the prevalence of freedom of religion is elaborated on in: Ungvári, 2021 220 | C-336/19, Centraal Israëlitisch Consistorie van België case, judgment, para. 82. 221 | C-336/19, Centraal Israëlitisch Consistorie van België case, judgment, para. 31.

222 | As it was already introduced in the first structural part of the current article, a similar reasoning emerged related to the exemption granted for the Sámi people by the Scandinavian countries. 223 | C-336/19, Centraal Israëlitisch Consistorie van België case, judgment, para. 85.; See furthermore the C-117/76 and 16/77, Ruckdeschel and others case, Judgment, 19 October 1977, para. 7 and the C-127/07, Arcelor Atlantique et Lorraine and others case, Judgment 16 December 2008, para. 23 224 | C-336/19, Centraal Israëlitisch Consistorie van België case, judgment, para. 86. 
Court was that Article 2 point ' $h$ ' defines 'cultural or sporting events' as 'events which are essentially and predominantly related to long-established cultural traditions or sporting activities, including racing or other forms of competitions, where there is no production of meat or other animal products or where that production is marginal compared to the event as such and not economically significant.'225 In this regard, the Court reiterated recital (16) of the Regulation, which states that 'Provided that those activities do not affect the market of products of animal origin and are not motivated by production purposes, it is appropriate to exclude the killing of animals taking place during those events from the scope of this Regulation'.

Thus - in the ECJ's interpretation - first, the 'cultural or sporting events' cannot be regarded as activities aimed at 'production of food' in the sense of Article 1 (1). Second, as the Court reiterated recital (14) of the Regulation, which states that hunting or recreational fishing activities take place in a context where conditions of killing are very different from those used for farmed animals.' As a consequence, 'if the concepts of 'hunting' and 'recreational fishing' are not to be rendered meaningless, it cannot be argued that those activities are capable of being carried out in respect of animals which have been stunned beforehand.'226

Regarding the above considerations, the ECJ stated that: 'It follows that the examination of the third question referred for a preliminary ruling has disclosed nothing capable of affecting the validity of point (c) of the first subparagraph of Article 26 (2) of Regulation No. 1099/2009'.

\section{Summarizing thoughts}

In section 1, the author introduced the historical, theological and scientific background of the shechita and halal slaughter. Based on his findings, the author drew two conclusions. First, in the author's view, it is not surprising that any restriction or ban on shechita is a cut to the quick for the followers of the Jewish faith, since shechita is the last foundation stone of their religious belief that was left intact during the forced assimilation and by the anti-Semitic movements of the $19^{\text {th }}$ and $20^{\text {th }}$ centuries. The author's second comment is related to the question that needs to be answered by every court which proceeds in cases about ritual slaughter, namely: 'Where is the equilibrium between the two concurring interests, that is, the freedom of religion and animal welfare considerations?' Considering that the developments in science provided us with methods that are suitable for stun and slaughter the animal in the most humane way, while religious prescriptions are also observed - that is to say, these methods are suitable for providing the prevalence of both the religious and the animal welfare requirements - where are the boundaries of the right to religious freedom and where shall it give ground to animal protection concerns? One may raise the question reversed, namely, where the boundaries of the 'rights of the animals'227 to their welfare are and where is the point where the 'rights of the animals' shall give ground to the right religious freedom. The author is in a quite lucky 
situation, since, unlike the judges of the ECtHR, the ECJ and the constitutional courts - he does not have to take sides. He is well aware of the fact that the reconciliation of animal welfare measures and religious prescriptions is not an easy task, as clearly shown by the high proportion of dissenting judges in the ECtHR's Cha'are Shalom ve Tsedek case and in the Polish Constitutional Court's religious slaughter case. As Advocate General Gerard Hogan wrote: 'a secular court cannot choose in relation to the matters of religious orthodoxy'. In accordance with these thoughts, the ECJ - just like the German Constitutional Court and unlike the Polish Constitutional Court, which elaborated on the 'morals' in a non-neutral way - strives to asses religious arguments from the outside, as a sociological question instead of examining it theologically and does well in this aspect, as some scholars argue. ${ }^{228}$ This article's author agrees with this opinion. Even if it is not for secular courts to decide in theological issues, once the case is brought before them, they have to make a decision and the 'outsider approach' is the only acceptable solution in a modern democratic society.

On the other hand, the author of the current article also argues that the issue needs to be settled through social and political debate. That is the way to find the equilibrium, ${ }^{229}$ regarding the fact that the scope of ECJ jurisdiction only covers the interpretation of EU law and decides on its validity. Following this, the author dispenses remarks on theological questions. Instead, he compares the opinion of the Advocate General and the ECJ judgment from an EU law perspective and draws his conclusions, namely that the latter is more coherent and more in conformity with EU law. That is, the author opines that the ECJ stated it correctly that member states have a margin of appreciation when it comes to weighting animal welfare considerations and the right to religious freedom. The Court provided more coherent reasoning than the Advocate General did. Furthermore, the author argues that the ECJ applied a more appropriate weighting of the relevant EU laws and principles. The two most apparent differences are that the ECJ put greater emphasis on evaluating Article 13 of the TFEU and that the ECJ applied the Gebhard-test when it came to the evaluation of the Member State's measures from the aspect of proportionality. The author contends that the lack of the latter in the Advocate General's opinion is rather apparent, and it contributed greatly to the fact that the ECJ provided a better interpretation. The author maintains his statements even if the ECJ judgment exhibits shortcomings as well - as it was introduced above - and holds that the Court failed to acknowledge the problems of interpretation attributable to the wording of the Regulation, something that the Advocate General did in his opinion.

228 | Pin and Witte, 2020, p. 255.

229 | This equilibrium may shift to either side as the attitude of society's evaluation on animal protection changes. These shifts are induced by societal changes - including the changes in the ethnic or religious composition of the society and the proportion of religious members of society. 


\section{Bibliography}

Anil, H., Miele, M., Luy, J., von Holleben, K., Bergeaud-Blackler, F., Velarde, A. (2010) 'Religious rules and requirements - Halal slaughter', Dialrel Reports, pp. 1-3. [Online]. https://www.dialrel.net/dialrel/images/halal-rules.pdf (Accessed: 24 September 2021).

Anne Peters (2018) 'De-humanisation? CJEU, Liga van Moskeeën en islamitische Organisaties Provincie Antwerpen on Religious Slaughter', EJIL:Talk! Blog of the European Journal of International Law (26 June 2018) [Online]. Available at: https:// www.ejiltalk.org/de-humanisation-cjeu-liga-van-moskeeen-en-islamitischeorganisaties-provincie-antwerpen-on-religious-slaughter/ (Accessed: 24 September 2021).

Anne Peters (2019) 'Religious Slaughter and Animal Welfare Revisited: CJEU, Liga van Moskeeen en Islamitische Organisaties Provincie Antwerpen', Canadian Journal of Comparative and Contemporary Law, 5, pp. 269-298.

Baron, S.W. (1938) 'The Jewish Question in the Nineteenth Century', Journal of Early Modern History, 10 (1), pp. 51-65.

Bartosiewicz László (2014) ‘Szívszorító hasonlóságok. Gondolatok a rituális állatvágás kapcsán', ókor: folyóirat az antik kultúrákról, 13 (3), pp. 77-81.

Bartosiewicz, L., Csiky, G., Gyarmati, J. (2008) 'Emberiességi szempontok és a hagyományos állatvágás két példája', Animal Welfare, Ethology and Housing Systems, 4 (3), pp. 130-149.

Benyusz, M., Pék, E., Marinkás, Gy. (2020) 'Vallási diszkrimináció megnövekedése Európában és az arra adott állami válaszok I. Vallásszabadság a nyugat-európai állam-egyház modellekben', Miskolci Jogi Szemle, 15 (2), pp. 148-173.

Berényi Mátyás (2013) 'A haszonállatok halal vágása, a rituális vágás élelmiszerbiztonsági kérdései, hatása a húsminőségre', PhD Dissertation, Debrecen, p. 63.

Berger, P. (1999) 'The Desecularization of the World: The Resurgence of Religion in World Politics', Grand Rapids, Eerdmans Publishing Company, p. 143.

Bomhoff, J. (2013) 'Balancing Constitutional Rights: the Origins and Meanings of Postwar Legal Discourse', Cambridge, Cambridge University Press, p. 280.

Borhegyi, P. (vezetőszerkesztő): ‘Történelem 11.', Kiadó: Oktatási Hivatal [Online]. Available at: https://www.nkp.hu/tankonyv/kiadasra_alkotokra_vonatkozo_adatok/ tortenelem_11 (Accessed: 24 September 2021).

Cuccurese, A., Sechi, P., Cenci Goga, B., Poeta, A., Cambiotti, V., Santella, E., Salamano, G. (2013) 'Acceptability of Electrical Stunning and Post-Cut Stunning Among Muslim Communities: A Possible Dialogue', Society \& Animals, 21, pp. 443-458.

Delahunty, R.J. (2015) 'Does Animal Welfare Trump Religious Liberty - The Danish Ban on Kosher and Halal Butchering', San Diego International Law Journal, 16 (2), pp. 341-380. 
Editorial Comments (2020) 'Not mastering the Treaties: The German Federal Constitutional Court's PSPP judgment', Common Market Law Review, 57 (4), pp. 965-978.

EFSA (2004) 'Welfare aspects of the main systems of stunning and killing the main commercial species of animals', The EFSA Journal, 45 (EFSA-Q-2003-093), pp. 1-29.

EFSA (2006) 'The welfare aspects of the main systems of stunning and killing applied to commercially farmed deer, goats, rabbits, ostriches, ducks, geese and quail', The EFSA Journal, 326, pp.1-18.

EFSA (2013) 'Scientific Opinion on monitoring procedures at slaughterhouses for bovines', The EFSA Journal, 11 (12):3460, p. 65.

EFSA (2013) 'The welfare aspects of the main systems of stunning and killing applied to commercially farmed deer, goats, rabbits, ostriches, ducks, geese and quail', The EFSA Journal (326), pp.1-18.

EFSA (2014) 'Opinion of the Scientific Panel on Animal Health and Welfare (AHAW) on a request from the Commission related to welfare aspects of the main systems of stunning and killing the main commercial species of animals' (6 July 2014) (EFSA, 2014a), p. 270. [Online]. Available at: https://www.efsa.europa.eu/en/efsajournal/pub/45 (Accessed: 24 September 2021).

EFSA (2014) 'Welfare aspects of the main systems of stunning and killing the main commercial species of animals', The EFSA Journal, 45, pp. 1-29. (EFSA, 2014b).

| EFSA (2020) 'Welfare of pigs at slaughter', The EFSA Journal, 18 (6):6148, p. 113.

Farouk, M.M., Al-Mazeedi, H.M. Sabow, A.B., Bekhit, A.E.D., Adeyemie, K.D., Sazili, A.Q., Ghani, A. (2014) 'Halal and Kosher Slaughter Methods and Meat Quality: A Review', Meat Science, 98 (3) ISSN 0309-1740, pp. 505-519.

Geiger, R., Khan, D.E., Kotzur, M. (eds.) (2015) European Union Treaties. Munich, C.H.Beck Hart, p. 225.

Gliszczytiska-Grabias, A., Sadurski, W., (2015) 'Freedom of Religion versus Humane Treatment of Animals: Polish Constitutional Tribunal's Judgment on Permissibility of Religious Slaughter', European Constitutional Law Review, 11 (3), pp. 596-608.

Grandin, T., Regenstein, J.M. (1994) 'Religious slaughter and animal welfare: A discussion for meat scientists', Meat Focus International, pp. 115-123 [Online]. Available at: https://www.grandin.com/ritual/kosher.slaugh.html (Accessed: 24 September 2021).

Heinz, G., Srisuvan, T. (2001) 'Guidelines for Humane Handling, Transport and Slaughter of Livestock', UN FAO RAP Publication (2001/4), p. 91.

Jütte, D. (2002) 'Tierschutz und Nationalsozialismus. Die Entstehung und die Auswirkungen des nationalsozialistischen Reichstierschutzgesetzes von 1933', Didaktik Biologie, 2, pp. 167-184. 
Kaminski, A.C. (2019) 'The "Stunning” Reality Behind Halal Meat Production', Environmental and Earth Law Journal, 9 (1), pp. 32-54 [Online]. Available at: https:// lawpublications.barry.edu/ejejj/vol9/iss1/2 (Accessed: 24 September 2021).

Kant, I. (1992) The Conflict of the Faculties (Translated by: Gregor, M.J.). Lincoln, University of Nebraska Press, p. 217.

Krajnyák, E. (2020) 'A lelkiismereti és vallásszabadság vizsgálata az emberi jogi bíróságok joggyakorlatának tükrében', in: Vadászné Bognár, G. - Dabasi-Halász, Zs. (eds.) Miskolci Egyetem Tudományos Diákköri Tanács, XIII., pp. 93-101.

Kymlicka, W., Donaldson, S. (2014) 'Animal Rights, Multiculturalism, and the Left', Journal of Social Philosophy, 45 (1), pp. 116-135.

Lerner, P., Rabello, A.M. (2006) 'The Prohibition of Ritual Slaughtering (Kosher Shechita and Halal) and Freedom of Religion of Minorities', Journal of Law and Religion, 22 (1), pp. 1-62.

Lipka, M., Hackett, C. (2017) 'Why Muslims are the world's fastest-growing religious group', Pew Research Center (6 April 2017) [Online]. Available at: https://www. pewresearch.org/fact-tank/2017/04/06/why-muslims-are-the-worlds-fastestgrowing-religious-group/ (24 September 2021).

Lottini, M., Giannino, M. (2019) 'Slaughtering without Pre-Stunning and EU Law on Animal Welfare: The Particular Case of Organic Production', European Food and Feed Law Review, 14 (6), pp. 502-511.

Lucci, D. (2008) 'Judaism and the Jews in the British Deists' Attacks on Revealed Religion', Hebraic Political Studies, 3 (2), pp. 177-214.

Marinkás, Gy. (2016) 'Az őslakos népek védelmének aktuális jogi kihívásai', PhD Dissertation, Miskolc, p. 406. - The theses of the dissertation in English language are online available at: https://drive.google.com/file/d/15rduuQHxlNNdlnt0UbKe7pJgyG MYNXW3/view?usp=sharing (Accessed: 24 September 2021)

Marinkás, Gy. (2017) 'Cultural Rights as a Tool of Protecting the Rights of Indigenous Peoples', In: Szabó, M., Láncos, P. L., Varga, R. (eds.): Hungarian Yearbook of International Law and European Law 2016 (Year of publication: 2017.), pp. 15-38.

Marinkás, Gy. (2018) 'Az őslakos népek védelmének aktuális jogi kihívásai', Miskolc, Private edition, p. 404. ISBN: 9786150038445 [Online]. Available at: https://drive. google.com/file/d/1wfOWtEKTwz5k1JJqyW95k765SoDkT4bN/view?usp=sharing (Accessed: 24 September 2021).

Marinkás, Gy. (2021) ‘A Covid-19 járvány európai uniós kezelése a „hatáskörök hálója”, avagy a rejtett hatáskörök révén'. Publicationes Universitatis Miskolcinensis, Sectio Juridica et Politica, Tomus XXXIX/1 (2021) pp. 138-166. (Hereafter: Marinkás 2021a). The revised and proofread version of the manuscript is available at: https://drive. google.com/file/d/11UWtJ0tcuo6o7w3-q6THjEM3QIn1Zm45/view? usp=sharing (Accessed: 24 September 2021).

Marinkás, Gy. (2021) 'Vallási diszkrimináció megnövekedése Európában és az arra adott állami válaszok II. Párhuzam a muszlimokat Európában érő - növekvő mértékű 
- diszkrimináció és a Közel-keleten a keresztények helyzete között', Miskolci Jogi Szemle, XVI. (1/1), pp. 52-75. (hereafter: Marinkás 2021b).

Metcalf, M.F. (1989) 'Regulating Slaughter: Animal Protection and Antisemitism in Scandinavia, 1880-1941', Patterns of Prejudice, 23 (3), pp. 32-48.

Morini, C. (2010) 'Secularism and Freedom of Religion', Israel Law Review, 43 (3), pp. 611-630.

Pin, A., Witte Jr., J. (2020) 'Meet the New Boss of Religious Freedom: The New Cases of the Court of Justice of the European Union', Texas International Law Journal, 55 (2), pp. 223-268.

Porat, I. (2020) 'The Starting at Home Principle: On Ritual Animal Slaughter, Male Circumcision and Proportionality', Oxford Journal of Legal Studies (2020/27).

Rahman, S.A., Phillips, C.J.C. (2017) 'Religion and Animal Welfare - An Islamic Perspective', Animals, 7 (2), pp. 1-11.

Rosen, S.D. (2004) 'Physiological insights into Shechita', The Veterinary Record, 154 (24), pp. 759-765.

Rosta, G. (2019) 'Szekularizáció? Deszekularizáció? Merre tart a vallási változás a világban?’, Magyar Tudomány, 180 (6), pp. 792-803.

Salamano, G., Cenci-Goga, B. (2015) 'Religious slaughtering, animal protection and freedom of religion', Industrie Alimentari, 53, pp. 5-10.

Schanda, B., Csiziné Schlosser, A. (2009) ‘Újabb fejlemények az Európai Emberi Jogi Bíróság vallásszabadsággal kapcsolatos gyakorlatában', Iustum Aequum Salutare, V (2), pp. 67-81.

Siegel, S.N. (2018) 'A new exodus? Explaining Jewish migration from Europe after the Cold War', Journal of Modern Jewish Studies, 17 (4), pp. 416-433.

Silver, J. (2011) 'Understanding Freedom of Religion in a Religious Industry: Kosher Slaughter (Shechita) and Animal Welfare', Victoria University of Wellington Law Review, 42 (4), pp. 671-704.

Skóra, A. (2019): 'Religious slaughter of animals in light of the EU and in the Polish law.' Uniwersytet Warmińsko-Mazurski w Olsztynie Studia Prawnoustrojowe 43, pp. 283296. (ORCID: 0000-0003-2169-5326)

Śledzińska-Simon, A. (2015) 'Ritual Animal Slaughter and Public Morality: a Comment on the Decision of the Polish Constitutional Tribunal', Verfassungsblog (29 Januar 2015) [Online]. Available at: https://verfassungsblog.de/ritual-animal-slaughterpublic-morality-comment-decision-polish-constitutional-tribunal/ (Accessed: 24 September 2021).

Sowery, K. (2018) 'Sentient beings and tradable products: The curious constitutional status of animals under Union law', Common Market Law Review, 55 (1), pp. 55-59.

Steven Reiss (2000) 'Why People Turn to Religion: A Motivational Analysis', Journal for the Scientific Study of Religion, 39 (1), pp. 47-52. 
Stremmelaar, A., Lucassen, L. (2018) Antisemitism and Immigration in Western Europe Today. Is there a connection? The case of the Netherlands. EVZ Foundation, p. 75. [Online]. Available at: https://bisa.bbk.ac.uk/wp-content/uploads/2020/09/BBKJ5998-Pears-Institute-Reports-NETHERLANDS-COUNTRY-REPORT-180420.pdf (Accessed: 24 September 2021).

Szilágyi, J. E. (2018) ‘VII. fejezet: Állatvédelmi jog’ in: Szilágyi, J.E. (ed.): Környezetjog II. kötet. Tanulmányok a környezetjogi gondolkodás köréből. Miskolc, Novotni Kiadó, p. 214.

Ungvári, Á. (2021) ‘A koronavírus-járvány hatása a szabad vallásgyakorlás jogára a Visegrádi Együttmüködés államaiban' (The place and the expected date of publication: Keresztény Jogakadémia, 2021).

Ungvári, Á., Hojnyák, D. (2020) ‘Az Európai Unió egyes tagállamainak koronavírusjárványra adott válasza, különös tekintettel a vizsgált államok által bevezetett különleges jogrendi szabályozásra', Miskolci Jogi Szemle, XV (1), pp. 122-138.

Večerek, V., Voslářová, E., Kameník, J., Machovcová, Z., Válková, L., Volfová, M., Konvalinová, J. (2020) 'The Impact of Deviation of the Stun Shot from the Ideal Point on Motor Paralysis in Cattle', Multidisciplinary Digital Publishing Institute (20 January 2020) [Online]. https://www.mdpi.com/2076-2615/10/2/280/pdf (Accessed: 24 September 2021).

Végh Ákos (2016) 'Állatokon végzett jólléti vizsgálatok és az elektromos kábítás mutatóinak összefüggései sertéseken', PhD Dissertation, Budapest, p. 73.

von Holleben, K., von Wenzlawowicz, M., Gregory, N., Anil, H., Velarde, A., Rodriguez, P., Cenci-Goga, B., Catanese, B., Lambooij, B. (2010) 'Report on good and adverse practices - Animal welfare concerns in relation to slaughter practices from the viewpoint of veterinary sciences', Dialrel Report (02/2010). Research done within the framework of the Dialrel Project: Religious slaughter, improving knowledge and expertise through dialogue and debate on issues of welfare, legislation and socio-economic aspects (European Union, FP6 Priority 5 "Food Quality and Safety").

von Wenzlawowicz, M., Holleben, K., Eser, E. (2012) 'Identifying reasons for stun failures in slaughterhouses for cattle and pigs: a field study', Animal Welfare, 21, pp. 51-60.

Witte Jr., J., Pin, A. (2021) 'Faith in Strasbourg and Luxembourg? The Fresh Rise of Religious Freedom Litigation in the Pan-European Courts', Emory Law Journal, 70 (3), pp. 587-661. [Online]. Available at https://scholarlycommons.law.emory.edu/elj/vol70/ iss3/2 (Accessed: 24 September 2021). 